\title{
Absorption-based algorithm of primary production for total and size-fractionated phytoplankton in coastal waters
}

\author{
Morvan K. Barnes ${ }^{1,5}$, Gavin H. Tilstone ${ }^{1, *}$, Timothy J. Smyth ${ }^{1}$, David J. Suggett ${ }^{2,7}$, \\ Rosa Astoreca $^{3,6}{ }^{\text {, Christiane Lancelot }}{ }^{3}$, Jacco C. Kromkamp ${ }^{4}$ \\ ${ }^{1}$ Plymouth Marine Laboratory, Prospect Place, West Hoe, Plymouth PL1 3DH, UK \\ ${ }^{2}$ School of Biological Sciences, University of Essex, Colchester, Essex CO4 3SQ, UK \\ ${ }^{3}$ Université Libre de Bruxelles, Ecologie des Systèmes Aquatiques, CP 221, Bd du Triomphe, 1050 Brussels, Belgium \\ ${ }^{4}$ Royal Netherlands Institute for Sea Research, PO box 140, 4400 AC Yerseke, The Netherlands \\ ${ }^{5}$ Present address: CNRS, Laboratoire d'Océanographie de Villefranche, Centre National de la Recherche Scientifique (CNRS) \\ and Université Pierre et Marie Curie (Paris 6), Villefranche-sur-Mer 06238, France \\ ${ }^{6}$ Present address: Université Libre de Bruxelles, Service de Chimie Quantique et Photophysique, CP 160/09, \\ 50 avenue F.D. Roosevelt, 1050 Brussels, Belgium \\ ${ }^{7}$ Present address: Climate Change Research Cluster, University of Technology Sydney, PO Box 123, Broadway, Sydney, \\ New South Wales 2007, Australia
}

\begin{abstract}
Most satellite models of production have been designed and calibrated for use in the open ocean. Coastal waters are optically more complex, and the use of chlorophyll a (chl a) as a first-order predictor of primary production may lead to substantial errors due to significant quantities of coloured dissolved organic matter (CDOM) and total suspended material (TSM) within the first optical depth. We demonstrate the use of phytoplankton absorption as a proxy to estimate primary production in the coastal waters of the North Sea and Western English Channel for both total, micro- and nano+pico-phytoplankton production. The method is implemented to extrapolate the absorption coefficient of phytoplankton and production at the sea surface to depth to give integrated fields of total and micro- and nano+pico-phytoplankton primary production using the peak in absorption coefficient at red wavelengths. The model is accurate to $8 \%$ in the Western English Channel and $22 \%$ in this region and the North Sea. By comparison, the accuracy of similar chl a based production models was $>250 \%$. The applicability of the method to autonomous optical sensors and remotely sensed aircraft data in both coastal and estuarine environments is discussed.
\end{abstract}

KEY WORDS: Absorption · Micro-phytoplankton · Nano-phytoplankton · North Sea $\cdot$ Primary production · Western English Channel

\section{INTRODUCTION}

Satellite-based estimates of primary production (PP) provide an attractive way to derive large synoptic datasets and have resulted in several alternative algorithms from which the water-leaving radiance can be related to the rate of production in both open ocean (Campbell et al. 2002) and coastal waters (Saba et al. 2010). Most PP algorithms use chlorophyll a (chl a) as a proxy for biomass and as a firstorder predictor of ocean productivity. There is con-

*Corresponding author: ghti@pml.ac.uk siderable variability in production per unit chlorophyll, which is often not captured using chl a based approaches (Campbell et al. 2002). To overcome this, a better parameterisation of the maximum photosynthetic rate is required, which is often based on temperature (Behrenfeld \& Falkowski 1997), although there are other factors that influence photosynthetic rates (Suggett et al. 2009), which temperature alone cannot capture. Variability of chlorophyll-specific production can be dominated by physiological shifts in intracellular pigments in response to varying

() The authors 2014. Open Access under Creative Commons by Attribution Licence. Use, distribution and reproduction are unrestricted. Authors and original publication must be credited. 
growth conditions (MacIntyre et al. 2002), which cause changes in phytoplankton absorption and can vary taxonomically and with cell physiological status (Falkowski \& Kolber 1995). Empirical descriptions of physiological variability have been shown to perform poorly when compared to local observations (Siegel et al. 2001). Furthermore, in coastal waters where phytoplankton is not the only dominant absorbing inherent optical property (IOP), the water-leaving radiance signal in the blue that is used in many standard chl a satellite algorithms also comes from absorption by coloured dissolved organic matter ( $\left.\mathrm{a}_{\mathrm{CDOM}}\right)$ and detrital material, i.e. non-algal particles $\left(\mathrm{a}_{\mathrm{NAP}}\right)$. This can result in a gross over-estimate of chl a (Tilstone et al. 2011) and therefore PP (Tilstone et al. 2005). Consequently, there has been a recent concerted effort to find a bio-optical replacement for 'conventional' chl a in remote sensing algorithms (Lee et al. 1996, Huot et al. 2007).

The rate of photosynthetic production by marine phytoplankton is essentially a function of the incident irradiance, the efficiency of light absorption by the cells' pigments and the quantum efficiency of carbon fixation. Phytoplankton light absorption is largely determined by pigment composition which varies between phytoplankton taxa and size, but collectively is determined by the bulk absorption and scattering properties of the community (Morel \& Maritorena 2001). Unlike chlorophyll concentration, light absorption by phytoplankton can be considered to be the cumulative response to environmental variables including irradiance, temperature and nutrient concentration; these same environmental factors are also thought to drive PP (Cullen et al. 1992). Light absorption by phytoplankton should therefore be a good predictor of primary production, particularly when phytoplankton is operating within the light-limited slope $\left(\alpha^{\mathrm{B}}\right)$, when carbon fixation increases linearly with irradiance, but less so when phytoplankton is light saturated and operating at the maximum photosynthetic rate. Marra et al. (2007) tested this concept for the surface waters of several geographically separate open ocean locations and found a promising linear relationship between surface production and spectrally-averaged phytoplankton pigment absorption. The analysis was restricted to surface open ocean waters and has not been tested to date in temperate and coastal waters.

Over the past decade, a range of remote sensing algorithms have been developed to detect the size and taxonomic composition of phytoplankton from ocean colour satellite data (Hirata et al. 2008). This has enabled high-resolution estimates of micro-, nano- and pico-phytoplankton biomass in the global ocean (Uitz et al. 2006). On the basis of these biomass models, satellite models of size-fractionated or classspecific PP are emerging (Uitz et al. 2010), although few have been developed for coastal waters.

The aim of this study was to investigate the use of phytoplankton light absorption as a predictor of PP at coastal locations in both the Western English Channel (WEC) and North Sea. Phytoplankton absorption measurements coincident with PP data measured during an annual seasonal cycle in 2009 in the WEC were used to calibrate models of surface and depthintegrated production for total, micro- and nano+picophytoplankton production. Data collected from 2010 to 2011 in the WEC and from 1999 to 2012 in the North Sea were subsequently used to validate the model, which was then compared with conventional chl a based models. The model could be applied to autonomous optical sensors and remotely sensed airborne data in both coastal and estuarine environments.

\section{MATERIALS AND METHODS}

\section{Study site and sampling}

Stn L4 in the WEC $\left(50^{\circ} 15^{\prime} \mathrm{N}, 4^{\circ} 13^{\prime} \mathrm{W}\right.$; Fig. 1) was sampled on a weekly basis from March 2009 to April 2011. Vertical profiles of temperature and fluores-

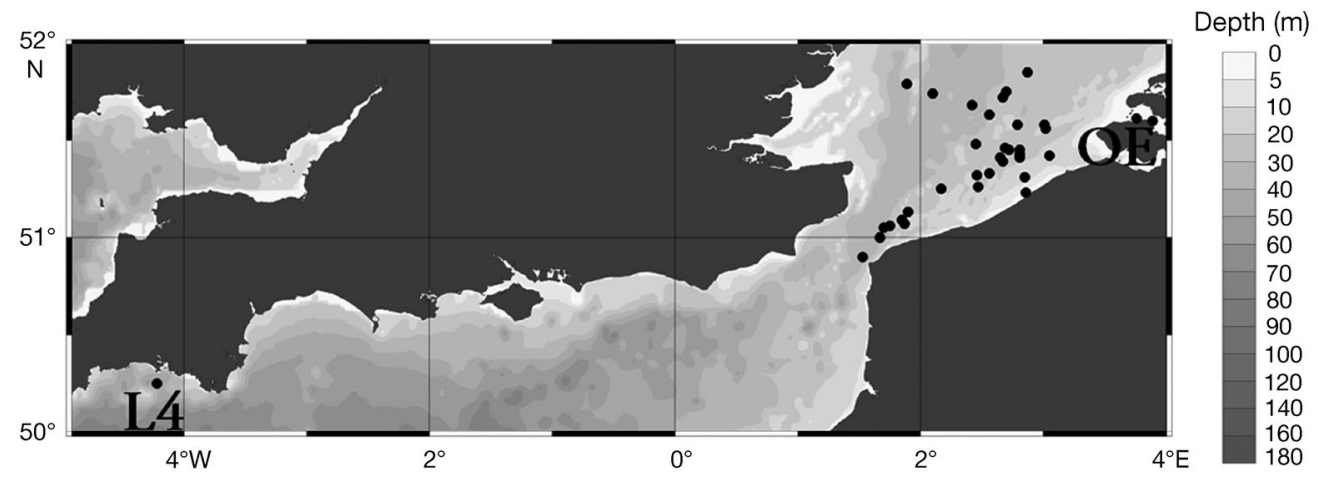

Fig. 1. Stations in the North Sea and Stn L4 in the Western English Channel. OE: Oosterschelde Estuary 
cence were obtained from SeaBird SBE19+ CTD casts. Water samples for laboratory analysis were collected from depths of $0,10,25$ and $50 \mathrm{~m}$ for the measurement of phytoplankton pigments, absorption coefficients and photosynthesis-irradiance curves to derive PP. In addition, 32 stations were sampled in the North Sea and Oosterschelde Estuary from April 1999 to October 2012.

\section{Chl $\boldsymbol{a}$ and absorption coefficients of phytoplankton, non-algal particles and coloured dissolved organic material}

Chl a from the WEC and the Oosterschelde Estuary were measured by high performance liquid chromatography (HPLC). Between 0.25 and 21 of seawater were filtered onto $25 \mathrm{~mm}$ GF/F filters and phytoplankton pigments were extracted in methanol containing the internal standard apo-carotenoate (SigmaAldrich). Chl a extraction was achieved using an ultrasonic probe following the methods outlined by Barlow et al. (1997). Pigments were identified using retention time and spectral match using Photo Diode Array (Jeffrey et al. 1997), and chl a concentration was calculated using response factors generated from calibration using a chl a standard (DHI Water and Environment). In addition to HPLC chl a analysis, size-fractionated chl a was also determined by sequentially filtering $250 \mathrm{ml}$ of seawater through 10, 2 and $0.2 \mu \mathrm{m}$ polycarbonate membrane filters from March-May and August-September 2009, AprilMay and July-September 2010 and March-April 2011. The filters were placed in $10 \mathrm{ml} 90 \%$ acetone and fluorescence was measured using a Turner Fluorometer according to Welschmeyer (1994). In addition, chl a samples from the North Sea were measured spectrophotometrically using the method and equations given by Lorenzen (1967). Between 0.25 and 21 of seawater were filtered onto $25 \mathrm{~mm} \mathrm{GF/C} \mathrm{filters} \mathrm{and}$ phytoplankton pigments were extracted in $90 \%$ acetone. Previous inter-comparisons have documented a difference of 5 to $30 \%$ between fluorometric and spectrophotometric techniques (Murray et al. 1986).

For North Sea and WEC samples, between 0.25 and 21 of seawater were filtered onto $25 \mathrm{~mm} \mathrm{GF/F}$ filters and the absorbance of the particulate material was measured from 350 to $750 \mathrm{~nm}$ at a $1 \mathrm{~nm}$ bandwidth using dual-beam Perkin Elmer Lambda 800 and UVIKON spectrophotometers retro-fitted with spectralon-coated integrating spheres, following the transmission-reflectance method of Tassan \& Ferrari (1995). Measurements were made of total particulate absorption $\left(a_{\text {part }}(\lambda)\right)$ and $a_{\mathrm{NAP}}(\lambda)$ before and after pigment extraction with $\mathrm{NaClO} 1 \%$ active chloride (Tassan \& Ferrari 1995). The pathlength amplification correction of Tassan \& Ferrari (1998) was used and phytoplankton absorption, $a_{\mathrm{ph}}(\lambda)$ was derived from the difference between $a_{\text {part }}(\lambda)$ and $a_{\text {NAP }}(\lambda)$. Samples from the Oosterschelde Estuary were measured on a Varian-Cary 100 UV/VIS spectrophotometer in a Sprectralon integrating sphere. The filters were placed in the centre of the sphere at an angle of $5^{\circ}$ relative to the light entrance port. $a_{\mathrm{ph}}(\lambda)$ was obtained after measuring the absorbance of the filters before and after pigment extraction using $\mathrm{NaClO} 1 \%$ active chloride using a pathlength amplification factor of 4.5 (Röttgers \& Gehnke 2012). For the preceding analyses, mean $a_{\mathrm{ph}}$ values were calculated for two $8 \mathrm{~nm}$ bands centered on the chl a absorption peaks (434$441 \mathrm{~nm}$ and $671-678 \mathrm{~nm}$ ) to avoid propagating small errors of the measurement into the model.

Seawater samples were also filtered through $0.2 \mu \mathrm{m}$ Whatman Nuclepore membrane filters into acidcleaned glassware for the determination of $a_{\mathrm{CDOM}}(\lambda)$. The first two $0.25 \mathrm{l}$ of the filtered seawater were discarded and $\mathrm{a}_{\mathrm{CDOM}}(\lambda)$ of the third aliquot of 0.251 was determined in a $10 \mathrm{~cm}$ quartz cuvette from 350 to $750 \mathrm{~nm}$ relative to a double-distilled MilliQ reference blank on the spectrophotometer described above. The $\mathrm{a}_{\mathrm{CDOM}}(\lambda)$ was calculated from the optical density of the sample and the cuvette pathlength (Tilstone et al. 2003a).

\section{Phytoplankton photosynthesis and PP}

In the WEC, PP was measured by photosynthesisirradiance (P-E) curves at $0,10,25$ and $50 \mathrm{~m}$ using linear photosynthetrons and $50 \mathrm{~W}$ tungsten halogen lamps, following Tilstone et al. (2003b). For each depth, 16 aliquots of $70 \mathrm{ml}$ within a polycarbonate bottle were inoculated with 5 to $10 \mu \mathrm{Ci}$ of ${ }^{14} \mathrm{C}$-labelled bicarbonate. Samples were maintained at in situ temperature during the $1.5 \mathrm{~h}$ incubations. Samples were then filtered onto $25 \mathrm{~mm}$ GF/F filters under a vacuum pressure no greater than $27 \mathrm{kPa}$. Filters were then exposed to concentrated $37 \%$ fuming hydrochloric acid for $12 \mathrm{~h}$, and beta-activity was counted using a Wallac 4040 scintillation counter following addition of $4 \mathrm{ml}$ of scintillation cocktail. Correction for quenching was performed using the external standard and the channel ratio methods. Size-fractionated P-E curves were also measured during the same periods in 2009, 2010 and 2011 as previously mentioned for chl $a$, by sequentially filtering samples after incubation onto 10 , 
2 and $0.2 \mu \mathrm{m}$ polycarbonate membrane filters to derive micro-, nano- and pico-specific P-E parameters. The equation of Platt et al. (1980) describing the light response of photosynthesis was fitted to the carbon fixation data using least squares non-linear regression in order to determine the photosynthetic parameters $P_{\mathrm{m}}{ }^{\mathrm{B}}, \alpha^{\mathrm{B}}$ and $\beta$ when $\mathrm{r}^{2} \geq 0.9$. Daily integrated

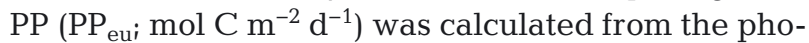
tosynthetically active radiation $\left(E_{\mathrm{PAR}}\right), \mathrm{chl}$ a and the photosynthetic parameters using the spectral model from Tilstone et al. (2003b). Integration was carried out at hourly steps and $1 \mathrm{~m}$ depth intervals from sea surface down to $0.1 \%$ of surface irradiance. $E_{\text {PAR }}$ was modelled using the approach of Gregg \& Carder (1990), modified to include the effects of clouds (Reed 1977) and using wind speed and percentage cloud cover from the European Centre for Medium Range Weather Forecasting ERA-40 dataset for the grid point closest to the location of Stn L4, as in Smyth et al. (2010). Chl a was linearly interpolated between depths from the discrete HPLC measurements (or fluorometry for size-fractionated samples). To estimate size-fractionated production, $\mathrm{a}_{\mathrm{ph}}(665)$ was split into micro- and nano+pico components based on diagnostic pigment ratios according to Eqs. (1-4) in Vidussi et al. (2001), weighted following the global pigment ratios of Uitz et al. (2006).

For the Oosterschelde Estuary, samples were collected on board RV 'Luctor', and 11 duplicate $70 \mathrm{ml}$ samples were incubated for $2 \mathrm{~h}$ using cool white fluorescent bulbs as described by Kromkamp et al. (2008). Hourly estimates of water column PP were calculated using the vertical irradiance attenuation coefficients $\left(\mathrm{K}_{\mathrm{d}}\right)$, the photosynthetic parameters $P_{\mathrm{m}}{ }^{\mathrm{B}}$ and $\alpha^{\mathrm{B}}$, chl a concentration and average hourly incident irradiance. The latter was measured continuously on the roof of the NIOZ institute in Yerseke, The Netherlands, using a LiCor LI-190 2-pi PAR quantum sensor, and the data were stored as hourly averages. The rate of $\mathrm{C}$-fixation at depth $\mathrm{z}$ was calculated by multiplying $\mathrm{P}^{\mathrm{B}}$ by the chl $a$. Due to the strong tidal mixing, chl a was assumed to be homogeneously distributed with depth. $\mathrm{PP}_{\mathrm{eu}}$ was calculated by integrating the hourly estimates and assuming that other parameters $\left(\mathrm{K}_{\mathrm{d}}\right.$, chl $\left.a, P_{\mathrm{m}}{ }^{\mathrm{B}}, \alpha^{\mathrm{B}}\right)$ did not change during the day. For Oosterschelde Estuary and WEC samples, the spectral irradiance $E_{z}(\lambda)$ at each location in the incubator was deduced from the relative mean spectrum of the lamps $E_{N}(\lambda)$ multiplied by the corresponding PAR.

For North Sea samples, P-E parameters were determined using the methods described by Mathot et al. (1992). In brief, samples were incubated for 0.75 to
$2 \mathrm{~h}$ between 09:00 and 15:00 h Coordinated Universal Time (UTC), under a gradient of ambient light obtained using neutral density filters in on-deck thermo-regulated incubators. Incident PAR ( $\mu$ mol quanta $\mathrm{m}^{-2} \mathrm{~s}^{-1}$ ) was continuously recorded on the upper deck of the ship using a plane sensor LI-COR LI-191SA, and sub-surface vertical profiles of PAR were obtained at 0.05 to $0.1 \mathrm{~m}$ steps, using a LICOR LI-192SA Underwater Quantum Sensor. Daily photosynthetic rates (mol $\mathrm{C} \mathrm{m}^{-2} \mathrm{~d}^{-1}$ ) were calculated by integrating the photosynthetic parameters derived from Platt et al. (1980) by the variation in PAR over the day and depth (vertical step of $0.25 \mathrm{~m}$ ) using incident PAR measured over the day and averaged at 15 min intervals.

\section{PP model comparisons}

Absorption-based models of PP were firstly calibrated with 2009 data from the WEC and then validated with independent data sets from the WEC collected in 2010 and 2011 and from the Oosterschelde Estuary and the North Sea collected between 1999 to 2012 (Fig. 1). Absorption-based PP was then compared with PP estimates obtained from the vertically generalized production model ( $\mathrm{PP}_{\mathrm{VGPM}}$ ) (Behrenfeld \& Falkowski 1997) and the semi-analytical model of Morel ( $\left.\mathrm{PP}_{\mathrm{M} 91}\right)$ (Morel 1991, Antoine et al. 1996) which were run using in situ data as input variables rather than satellite data. $\mathrm{PP}_{\mathrm{VGPM}}$ was modified from a water column total to a surface value by calculating the attenuation coefficient $(\mathrm{k})$ from the euphotic depth $\mathrm{Z}_{\text {eu }}$ and assuming uniform vertical biomass and exponential decline in production from the surface. Both models were parameterised using in situ measurements of chl $a$ and temperature so as to test relative model skill rather than satellite retrieval algorithms. Weibull curves (Weibull 1951) were parameterised using mean seasonal CTD fluorescence profiles using Sigmaplot ${ }^{\mathrm{TM}}$ and subsequently applied to sea surface $a_{\text {ph }}$ to reconstruct vertical variability in this parameter. Analysis of covariance (ANCOVA) was performed using the general linear model function in Minitab ${ }^{\mathrm{TM}}$ to compare regressions between modelled and in situ data.

\section{Statistical and model analysis}

Linear and log-linear regressions were used to assess relationships between bio-optical variables and primary production. To evaluate algorithm per- 
formance, we used the root-mean square error (RMSE) of the difference error between measured and algorithm-estimated values at each station as described by Campbell et al. (2002). The geometric mean and one-sigma range of the inverse transformed ratio between satellite and measured values are given by $\mathrm{M}\left(\mathrm{F}_{\text {med }}\right), \mathrm{M}-\mathrm{S}\left(\mathrm{F}_{\min }\right), \mathrm{M}+\mathrm{S}\left(\mathrm{F}_{\max }\right)$ and were used as algorithm performance indices. The relative (RPD) and absolute percentage differences (APD) were calculated following Antoine et al. (2008). ANCOVA was employed to assess significant differences between regressions, where $F$ is the mean square to mean square error ratio, and $\mathrm{p}$ is the ANCOVA critical significance value at the $5 \%$ level.

\section{RESULTS}

\section{Phytoplankton optical absorption}

The relative contribution of $\mathrm{a}_{\mathrm{ph}}, \mathrm{a}_{\mathrm{NAP}}, \mathrm{a}_{\mathrm{CDOM}}$ and seawater to total light absorption at Stn L4 varied by wavelength and between seasons (Fig. 2). At $442 \mathrm{~nm}$ (the blue peak of the chl a absorption spectrum), $a_{\text {CDOM }}$ was the highest absorbing component in the water column during spring, summer and autumn, followed by $a_{\text {ph }}$. In winter, $a_{\mathrm{NAP}}$ was as high as $a_{\mathrm{ph}}$. At this wavelength $a_{\mathrm{CDOM}}$ varied by an order of magnitude between 2009 and 2010 from 0.009 to $0.139 \mathrm{~m}^{-1}$, but in winter and autumn, mean $a_{\mathrm{CDOM}}$ was 3.4 -fold and 2.9-fold greater than $a_{\mathrm{ph}}$. This illustrates that if remote sensing reflectance at $442 \mathrm{~nm}$ is used to estimate either chl a or $a_{\text {ph }}$ at Stn L4, the majority of the signal would be from $a_{\mathrm{CDOM}}$, which would potentially give rise to errors in the estimation of chl a. Conversely in the red at $665 \mathrm{~nm}$, both $a_{\mathrm{CDOM}}$ and $a_{\mathrm{NAP}}$ were very low $\left(<0.04 \mathrm{~m}^{-1}\right)$ whilst $a_{\mathrm{ph}}$ was always consistently higher. The absorption of seawater $\left(a_{\mathrm{w}}\right)$ is also high $\left(0.431 \mathrm{~m}^{-1}\right)$ and is 30 times higher than the annual mean $a_{\mathrm{ph}}(665)$. However, $a_{\mathrm{w}}(665)$ is known and relatively constant (Pope \& Fry 1997), although this does depend on temperature, which makes it relatively simple to estimate $a_{\mathrm{ph}}(665)$, as long as it is above the radiometric error of detection.

From 2009 to 2010, $a_{\mathrm{ph}}(442)$ and $a_{\mathrm{ph}}(665)$ varied from 0.004 to $0.568 \mathrm{~m}^{-1}$ (coefficient of variation, $\mathrm{CV}$ : 1.18, SD: 0.042 ) and 0.003 to $0.204 \mathrm{~m}^{-1}$ (CV 1.25, SD 0.018), respectively, with clear temporal and vertical

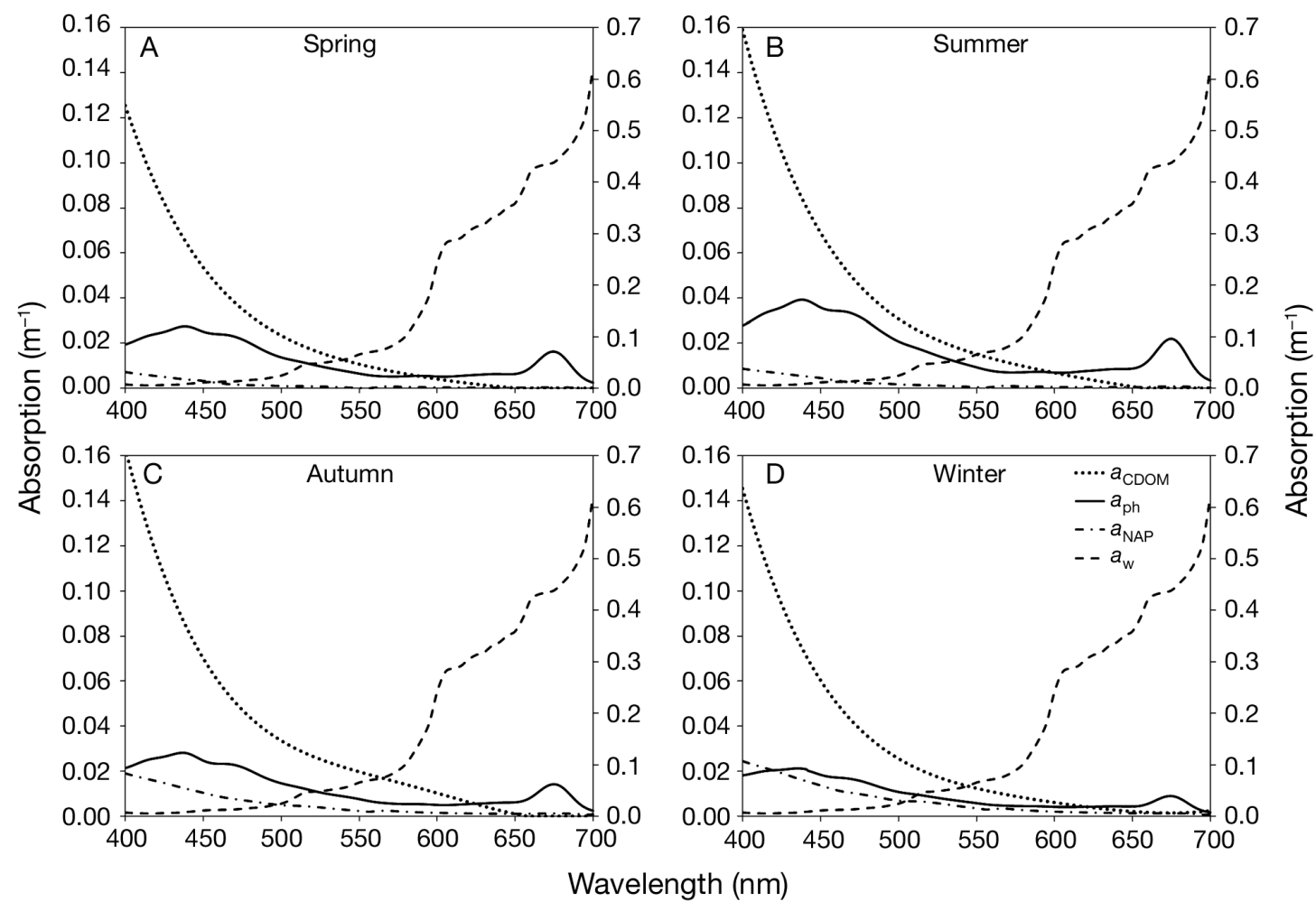

Fig. 2. Mean seasonal absorption spectra (2009-2010) of phytoplankton $\left(a_{\mathrm{ph}}\right)$, non-algal particles $\left(a_{\mathrm{NAP}}\right)$ and coloured dissolved organic matter ( $a_{\mathrm{CDOM}}$; all left axis) at Stn L4 in the Western English Channel and the absorption spectrum of seawater $\left(a_{\mathrm{w}}\right)$ from Pope \& Fry (1997) (right hand axis) 
heterogeneity observed with depth (Fig. 3). Absorption maxima were observed during August-September 2009 between 10 and $25 \mathrm{~m}$, when $a_{\mathrm{ph}}(442)$ and $a_{\mathrm{ph}}(665)$ were 0.568 and $0.178 \mathrm{~m}^{-1}$, respectively, which corresponded to a bloom of Karenia mikimotoi. The secondary peak was in May-June 2010 at $50 \mathrm{~m}$, associated with a sinking bloom of Phaeocystis globosa, when $a_{\mathrm{ph}}(442)$ reached $0.205 \mathrm{~m}^{-1}$ and $a_{\mathrm{ph}}(665)$ was $0.204 \mathrm{~m}^{-1}$. These $a_{\mathrm{ph}}$ maxima were only observed at depth and not in surface samples (Fig. 3). Values of $a_{\mathrm{ph}}(665)$ were the lowest as expected, followed by $a_{\mathrm{ph}}(\mathrm{PAR})$ whilst $a_{\mathrm{ph}}(442)$ was almost double $a_{\mathrm{ph}}(665)$. The 3 measurements of absorption co-varied strongly $(0.876<\mathrm{r}<0.977, \mathrm{p}<0.001)$ and conserved proportionality.

Significant regressions were observed between (1) $\mathrm{PP}$ at the surface $\left(\mathrm{PP}_{0}\right)$ and the product of $E_{\mathrm{PAR}}$ and $a_{\mathrm{ph}}(442)$, (2) $\mathrm{PP}_{0}$ and $a_{\mathrm{ph}}(665)$ and (3) $\mathrm{PP}_{0}$ and the mean phytoplankton absorption coefficient over the PAR spectrum $\left(a_{\mathrm{ph}}(\mathrm{PAR})\right)$ (Fig. 4). The slope of $E_{\mathrm{PAR}} \times$ $a_{\mathrm{ph}}(\mathrm{PAR})$ gives the quantum yield. The most significant relationship was $E_{\mathrm{PAR}} \times a_{\mathrm{ph}}(665)$ which explained $88 \%$ of the total variance in $\mathrm{PP}_{0}$ from 2009 (Eq. 3 in Table 1). Only $78 \%$ of the variation in $\mathrm{PP}_{0}$ from 2009 could be explained by the product of $a_{\text {ph}}(442)$ (Eq. 2 in Table 1).

The slope of the product with $a_{\mathrm{ph}}(442)$ was significantly lower than $a_{\mathrm{ph}}(665)$ and $a_{\mathrm{ph}}(\mathrm{PAR})\left(F_{2,87}=61.1\right.$, $\mathrm{p}<0.001)$. For the product of $a_{\mathrm{ph}}(665)$, differences in the relationship between seasons were also tested and showed that the regression for the summer was borderline significant at the $5 \%$ level $\left(F_{3,74}=2.72, \mathrm{p}=\right.$ 0.0489), with a slope $19 \%$ higher than the other seasons.

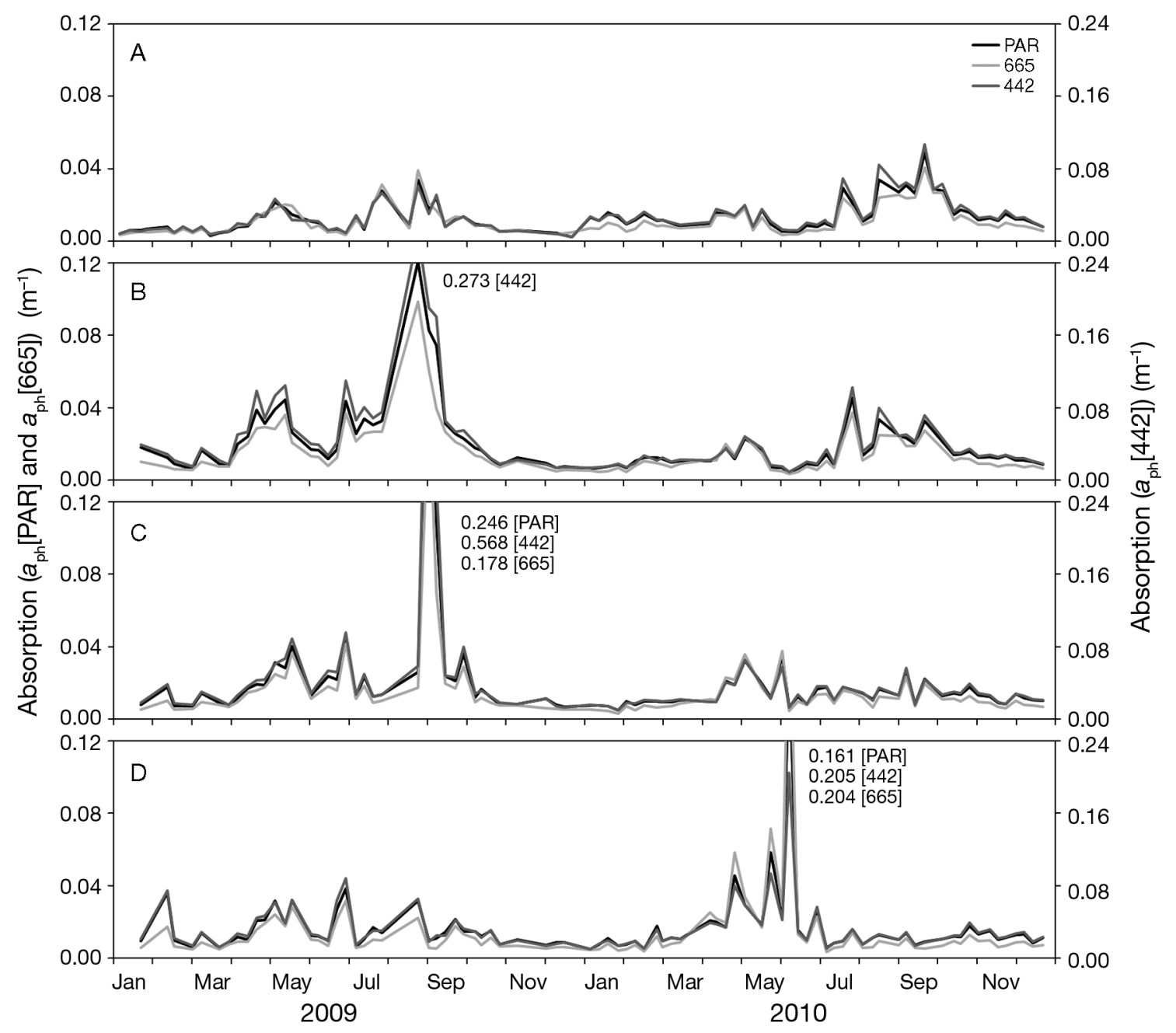

Fig. 3. Time series of the absorption coefficient of phytoplankton at photosynthetically active radiation $\left(\mathrm{a}_{\mathrm{ph}}(\mathrm{PAR})\right)$, $\mathrm{a}_{\mathrm{ph}}(442)$ and $\mathrm{a}_{\mathrm{ph}}(665)$ at Stn L4 from 2009 to 2010 at (A) $0 \mathrm{~m}$, (B) $10 \mathrm{~m}$, (C) $25 \mathrm{~m}$ and (D) $50 \mathrm{~m}$. The $y$-axis has been truncated for clarity omitting the highest $\mathrm{a}_{\mathrm{ph}}$ values which are indicated in (B), (C) and (D) 

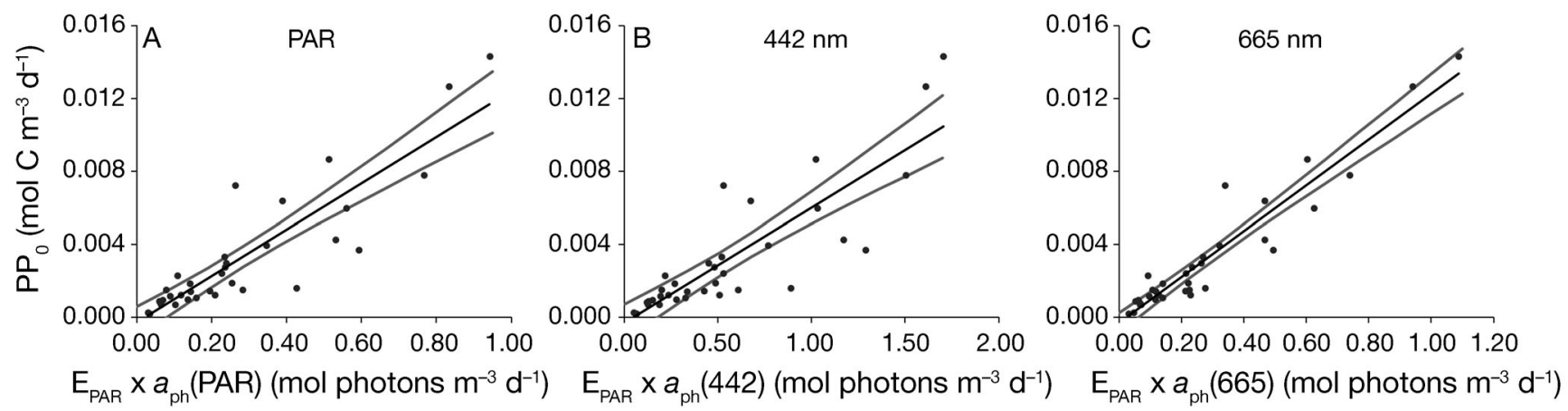

Fig. 4. Relationships between primary production at the surface $\left(\mathrm{PP}_{0}\right)$ and $E_{(\mathrm{PAR})}$ multiplied by (A) $a_{\mathrm{ph}}(\mathrm{PAR}),(\mathrm{B}) a_{\mathrm{ph}}(442)$ and $(\mathrm{C})$ $a_{\mathrm{ph}}(665)$ for data collected in 2009 from Stn L4 in the Western English Channel. Linear regressions (dark line) and 95\% confidence intervals (grey lines) are shown for each

Table 1. Equations and associated statistics for the absorption coefficient of phytoplankton $\left(\mathrm{a}_{\mathrm{ph}}\right)$-based surface and water column primary production (PP) model development and validation. For each equation, standard errors for the slope and constant are shown in parentheses. M: micro-phytoplankton; NP: nano+pico-phytoplankton; WEC: Western English Channel; $E_{\mathrm{PAR}}$ : photosynthetically active radiation; cst: constant profile; mod: modulated profile; $\mathrm{PP}_{0}$ : $\mathrm{PP}$ at the surface $\left(\mathrm{mol} \mathrm{C} \mathrm{m}^{-3} \mathrm{~d}^{-1}\right) ; \mathrm{PP}_{\mathrm{z}}$ : depth resolved PP $\left(\mathrm{mol} \mathrm{C} \mathrm{m} \mathrm{d}^{-3} \mathrm{~d}^{-1}\right)$; $\mathrm{PP}_{\mathrm{APH}}$ : water column integrated PP derived from $\mathrm{E}_{\mathrm{PAR}} \times a_{\mathrm{ph}}(665)\left(\mathrm{mol} \mathrm{C} \mathrm{m}^{-2} \mathrm{~d}^{-1}\right) ; \mathrm{PP}_{\mathrm{M} 91}$ : PP from the Morel (1991) model; PP $_{\text {eu }}$ : daily integrated PP; VGPM: vertically generalized production model; NS: North Sea

\begin{tabular}{|c|c|c|c|c|c|c|c|c|c|}
\hline $\begin{array}{l}\text { Eq. } \\
\text { no. }\end{array}$ & Area & $\begin{array}{l}\text { Depth } \\
\text { (m) }\end{array}$ & Year & Model & $a_{\mathrm{ph}}$ & $\mathrm{N}$ & Equation & $\mathrm{R}^{2}$ & $F^{\mathrm{a}}$ \\
\hline \multicolumn{10}{|c|}{ Surface model parameterisation } \\
\hline 1 & WEC & 0 & 2009 & $a_{\mathrm{ph}}$ & PAR & 34 & $\mathrm{PP}_{0}=0.0127( \pm 0.0012) \times\left(\mathrm{a}_{\mathrm{ph}} \times E_{\mathrm{PAR}}\right)-0.00029( \pm 0.00043)$ & 0.787 & 118.30 \\
\hline 2 & WEC & 0 & 2009 & $a_{\mathrm{ph}}$ & Blue & 34 & $\mathrm{PP}_{0}=0.0062( \pm 0.0007) \times\left(\mathrm{a}_{\mathrm{ph}} \times E_{\mathrm{PAR}}\right)-0.00028( \pm 0.00050)$ & 0.718 & 81.67 \\
\hline 3 & WEC & 0 & 2009 & $a_{\mathrm{ph}}$ & Red & 34 & $\mathrm{PP}_{0}=0.0120( \pm 0.0007) \times\left(\mathrm{a}_{\mathrm{ph}} \times E_{\mathrm{PAR}}\right)-0.00022( \pm 0.00026)$ & 0.910 & 325.52 \\
\hline \multicolumn{10}{|c|}{ Surface model validation } \\
\hline 4 & WEC & 0 & 2010 & $\mathrm{a}_{\mathrm{ph}}$ & PAR & 45 & $\mathrm{PP}_{0}=0.0099( \pm 0.0008) \times\left(\mathrm{a}_{\mathrm{ph}} \times E_{\mathrm{PAR}}\right)-0.00003( \pm 0.00024)$ & 0.791 & 162.94 \\
\hline 5 & WEC & 0 & 2010 & $a_{\mathrm{ph}}$ & Blue & 45 & $\mathrm{PP}_{0}=0.0043( \pm 0.0003) \times\left(\mathrm{a}_{\mathrm{ph}} \times E_{\mathrm{PAR}}\right)-0.00006( \pm 0.00023)$ & 0.810 & 183.89 \\
\hline 6 & WEC & 0 & 2010 & $a_{\mathrm{ph}}$ & Red & 45 & $\mathrm{PP}_{0}=0.0109( \pm 0.0008) \times\left(\mathrm{a}_{\mathrm{ph}} \times E_{\mathrm{PAR}}\right)-0.00018( \pm 0.00021)$ & 0.824 & 201.02 \\
\hline \multicolumn{10}{|c|}{ Depth-resolved model } \\
\hline 7 & WEC & $0,10,25,50$ & $2009-10^{\mathrm{b}}$ & $\mathrm{a}_{\mathrm{ph}}$ & Red & 190 & $\log _{10} \mathrm{PP}_{\mathrm{z}}=0.920( \pm 0.026) \times \log _{10}\left(\mathrm{a}_{\mathrm{ph}} \times E_{\mathrm{PAR}}\right)-1.985( \pm 0.045)$ & 0.867 & 1221.3 \\
\hline \multicolumn{10}{|c|}{ Depth-integration method } \\
\hline 8 & WEC & $0-50$ & $2009-10^{\mathrm{b}}$ & $\mathrm{a}_{\mathrm{ph}}(\mathrm{cst})$ & Red & 80 & $\mathrm{PP}_{\mathrm{APH}}=1.043( \pm 0.085) \times \mathrm{PP}_{\mathrm{eu}}+0.0027( \pm 0.0035)$ & 0.653 & 149.46 \\
\hline 9 & WEC & $0-50$ & $2009-10^{\mathrm{b}}$ & $\mathrm{a}_{\mathrm{ph}}(\mathrm{mod})$ & Red & 80 & $\mathrm{PP}_{\mathrm{APH}}=0.848( \pm 0.059) \times \mathrm{PP}_{\mathrm{eu}}+0.0028( \pm 0.0025)$ & 0.722 & 205.84 \\
\hline 10 & NS & $0-50$ & Various & $\mathrm{a}_{\mathrm{ph}}(\mathrm{mod})$ & 676 & 42 & $\mathrm{PP}_{\mathrm{APH}}=0.0081( \pm 0.00009) \times\left(\mathrm{a}_{\mathrm{ph}} \times E_{\mathrm{PAR}}\right)+0.0146( \pm 0.0061)$ & 0.669 & 84.05 \\
\hline \multicolumn{10}{|c|}{ Depth-resolved model validation } \\
\hline 11 & $\mathrm{WEC}+\mathrm{NS}$ & $0-50$ & $2009-10^{\mathrm{b}}$ & $\mathrm{a}_{\mathrm{ph}}$ & Red & 88 & $\log _{10} \mathrm{PP}_{\mathrm{APH}}=0.733( \pm 0.050) \times \log _{10} \mathrm{PP}_{\mathrm{eu}}-0.395( \pm 0.081)$ & 0.712 & 212.15 \\
\hline 12 & WEC & $0-50$ & $2009-10^{\mathrm{b}}$ & M91 & $\mathrm{Chl}$ & 47 & $\log _{10} \mathrm{PP}_{\mathrm{M} 91}=0.618( \pm 0.057) \times \log _{10} \mathrm{PP}_{\mathrm{eu}}-0.099( \pm 0.100)$ & 0.726 & 119.28 \\
\hline 13 & $\mathrm{WEC}+\mathrm{NS}$ & $0-50$ & $2009-10^{\mathrm{b}}$ & VGPM & Chl & 89 & $\log _{10} \mathrm{PP}_{\mathrm{VGPM}}=0.766( \pm 0.052) \times \log _{10} \mathrm{PP}_{\mathrm{eu}}-0.194( \pm 0.084)$ & 0.708 & 214.46 \\
\hline \multicolumn{10}{|c|}{ Size-fractionated absorption } \\
\hline 14 & WEC & $0,10,25,50$ & $2009-11$ & Chl(M) & Red & 67 & $\mathrm{a}_{\mathrm{ph}}=0.0162( \pm 0.0014) \times \mathrm{Chl}(\mathrm{M})+0.0063( \pm 0.0027)$ & 0.653 & 125.40 \\
\hline 15 & WEC & $0,10,25,50$ & 2009-11 & Chl(NP) & Red & 11 & $\mathrm{a}_{\mathrm{ph}}=0.0134( \pm 0.0017) \times \operatorname{Chl}(\mathrm{NP})+0.0075( \pm 0.0017)$ & 0.863 & 63.70 \\
\hline \multicolumn{10}{|c|}{ Size-fractionated model } \\
\hline 16 & WEC & $0,10,25,50$ & 2009-11 & $\mathrm{a}_{\mathrm{ph}}(\mathrm{M})$ & Red & 70 & $\log _{10} \mathrm{PP}_{\mathrm{z}}=0.938( \pm 0.054) \times \log _{10}\left(\mathrm{a}_{\mathrm{ph}} \times E_{\mathrm{PAR}}\right)-2.012( \pm 0.100)$ & 0.813 & 300.87 \\
\hline 17 & WEC & $0,10,25,50$ & 2009-11 & $a_{p h}(N P)$ & Red & 70 & $\log _{10} \mathrm{PP}_{\mathrm{z}}=0.758( \pm 0.037) \times \log _{10}\left(\mathrm{a}_{\mathrm{ph}} \times E_{\mathrm{PAR}}\right)-1.902( \pm 0.092)$ & 0.859 & 420.20 \\
\hline
\end{tabular}

The regression equations for the product of $\mathrm{PP}_{0}$ and $E_{\mathrm{PAR}}$ and $a_{\mathrm{ph}}(442), a_{\mathrm{ph}}(665)$ and $a_{\mathrm{ph}}(\mathrm{PAR})$ derived using the WEC data in 2009 were validated against the data collected in 2010 and 2011 (Fig. 5). Again the best predictor of $\mathrm{PP}_{0}$ was for the relationship between $E_{\mathrm{PAR}}$ and $a_{\mathrm{ph}}(665)$ (Fig. 5c; Eq. 6 in Table 1). The regression slope was slightly lower than that determined for surface $a_{\mathrm{ph}}(\mathrm{PAR})$ reconstructed from individual pigments in the Arabian Sea by Marra et al. (2007) (dashed line in Fig. 5). RMSE, calculated between 2009 model and 2010-2011 validation data, was lowest for $a_{\mathrm{ph}}(665)\left(0.029 \mathrm{~mol} \mathrm{C} \mathrm{m}^{-3} \mathrm{~d}^{-1}\right)$ and highest for $a_{\mathrm{ph}}(442)$ (0.040) with intermediate RMSE for $a_{\mathrm{ph}}(\mathrm{PAR})(0.036)$. 

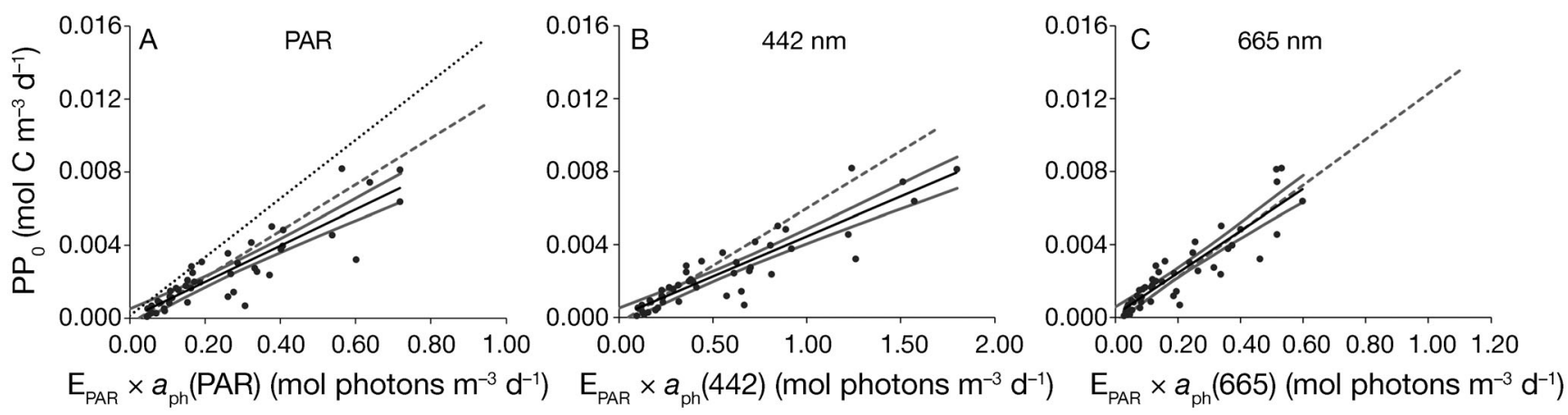

Fig. 5. Relationships between $\mathrm{PP}_{0}$ and (A) $a_{\mathrm{ph}}(\mathrm{PAR}),(\mathrm{B}) a_{\mathrm{ph}}(442)$ and $(\mathrm{C}) a_{\mathrm{ph}}(665)$ and their product with surface irradiance $E_{\mathrm{PAR}}$ for data collected in 2010 to 2011 from Stn L4 in the Western English Channel. Linear regressions (dark line), $95 \%$ confidence intervals (grey lines) and relationships for 2009 (dashed lines) are shown for each. The relationship of Marra et al. (2007) for $a_{\mathrm{ph}}(\mathrm{PAR})$ in the Arabian Sea is given as the dashed line in (A)

\section{Depth-integrated production from $a_{\mathrm{ph}}$}

Data were restricted to the $>1 \%$ light level resulting in two-thirds fewer measurements at $50 \mathrm{~m}$ than at the surface. The relationship between depthresolved $\mathrm{PP}\left(\mathrm{PP}_{\mathrm{z}}\right)$ and $E_{\mathrm{PAR}}$ multiplied by $a_{\mathrm{ph}}(665)$ was conserved throughout the water column (Fig. 6), and $88 \%$ of the variance in $\mathrm{PP}_{\mathrm{z}}$ could be explained through the product of $a_{\mathrm{ph}}$ and $E_{\mathrm{PAR}}$ (Eq. 7 in Table 1).

Two approaches to determine total water column production from surface $a_{\mathrm{ph}}$ were evaluated. For both, $\mathrm{PP}_{\mathrm{APH}}$ was estimated by applying Eq. (7) from Table 1 to depth-specific irradiance and absorption calculated at $1 \mathrm{~m}$ depth intervals, whereby:

$$
\begin{aligned}
& \log P P_{\mathrm{APH}}=0.926 \times \\
& \int_{z=0}^{50} \log \left(E_{\mathrm{PAR}}(z) \cdot \alpha p h\{665\}(z)\right) \cdot d z-1.984
\end{aligned}
$$

The 2 approaches differ in the determination of $a_{\mathrm{ph}}(665)(\mathrm{z})$ : the first assumes vertical homogeneity of $a_{\text {ph }}$ (defined as 'cst' in Table 1) whilst the second approach allows for seasonal modulation of $a_{\mathrm{ph}}$ throughout the water column (defined as 'mod' in Table 1) based on 4 characteristic Weibull curves of the chl a biomass (Fig. 7). The parameterisation of the Weibull curves was performed for Stn L4 waters by using mean curve parameters from CTD-derived fluorescence profiles from 0 to $50 \mathrm{~m}$ depth for winter, spring, summer and autumn (Fig. 7). In winter, the vertical structure was largely homogeneous, whereas in other seasons the biomass maximum was around $10 \mathrm{~m}$ depth. The largest vertical heterogeneity occurred during summer when biomass was twice as high at $10 \mathrm{~m}$ depth than at the surface and $40 \%$ less at $50 \mathrm{~m}$ depth. This could be due to nonphotosynthetic quenching of the fluorescence (Cullen \&

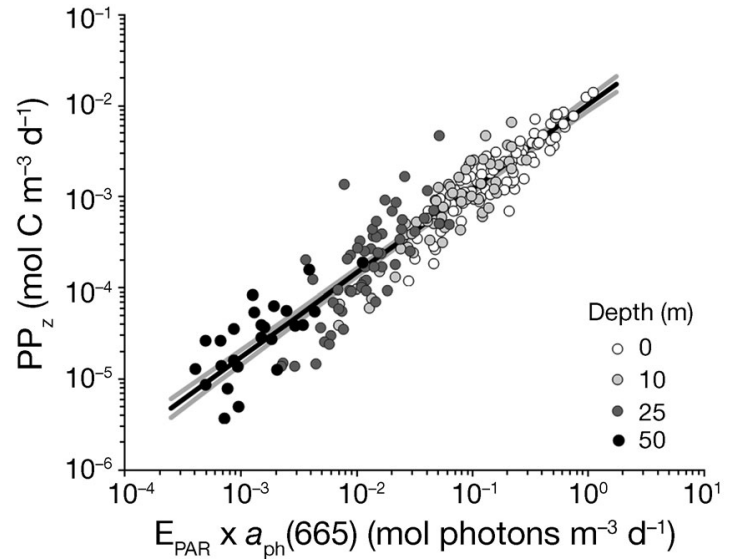

Fig. 6. Log-linear regression of depth-specific primary production $\left(\mathrm{PP}_{\mathrm{z}}\right)$ and $\mathrm{a}_{\mathrm{ph}}(665)$ multiplied by $E_{\mathrm{PAR}}$ for $2009-2010$ data from the Western English Channel. Regression line (dark line) and 95\% confidence intervals (grey lines) are shown

Lewis 1995), although this should be small, as the majority of the CTD casts were taken before 10:00 $\mathrm{h}$ UCT.

Comparison between in situ depth-integrated production $\mathrm{PP}_{\mathrm{eu}}$ and $\mathrm{PP}_{\mathrm{APH}}$ calculated using vertically constant (Fig. 8A) and vertically modulated $a_{\mathrm{ph}}(665)$ (Fig. 8B) showed some differences between the approaches. An ANCOVA test for homogeneity of regressions (PPz versus $\left.E_{\mathrm{PAR}} \times a_{\mathrm{ph}}(665)\right)$ performed for the depths 0,10 and $25-50 \mathrm{~m}$ showed no significant differences between depths $\left(F_{2,220}=0.81, \mathrm{p}=\right.$ 0.447 ). Assuming vertical homogeneity, $\mathrm{PP}_{\mathrm{APH}}$ and $\mathrm{PP}_{\text {eu }}$ showed reasonable agreement with an $\mathrm{R}^{2}$ of 0.66. However, depth-integrated production was underestimated in winter and overestimated in spring, further suggesting that non-photosynthetic quenching did not play a role in spring. By modulating $a_{\mathrm{ph}}$ vertically, the regression fit is improved to 


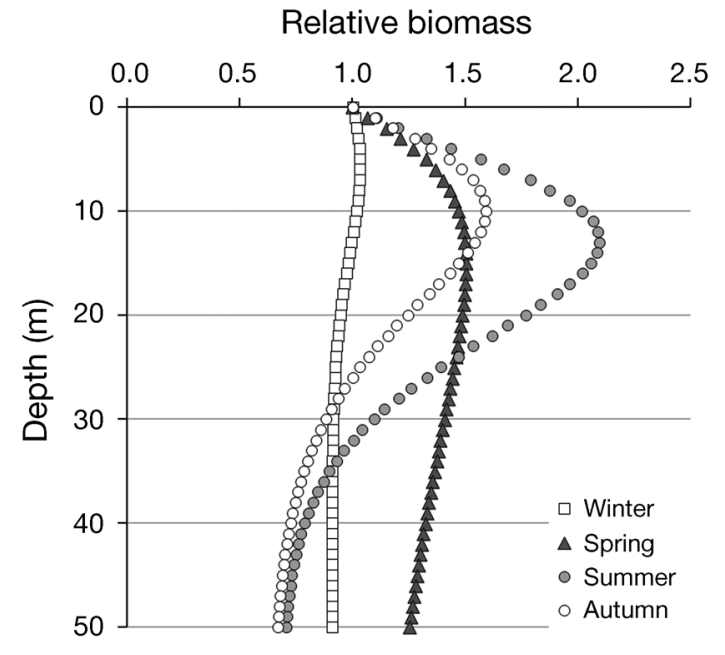

Fig. 7. Seasonal Weibull curves delineating vertical changes in phytoplankton biomass relative to surface biomass parameterised using CTD fluorescence profiles

0.73 and no difference between seasons was evident. In both cases, the slope of the regression was close to the 1:1 line (with the 1:1 within the 95\% confidence interval of the regression) with a very low offset.

\section{Comparison with chl a based models of PP}

The use of $a_{\mathrm{ph}}(665)$ as a first-order predictor of water column production from 2009 was also compared to the more widely used chl a based models against data collected in the WEC, the North Sea and the Oosterschelde (Fig. 9). For the North Sea and Oosterschelde, $a_{\mathrm{ph}}$ at $665 \mathrm{~nm}$ was used in Eq. (7b) to estimate PP. ANCOVA for homogeneity of regressions showed no significant difference between the regression given in Eq. (9) in Table 1 for the WEC and the analogous equation for the North Sea $(F=$ $2.21, \mathrm{p}=0.139$ ).

For these data, $\mathrm{PP}_{\mathrm{VGPM}}$ consistently overestimated $\mathrm{PP}_{\text {eu }}$ with a high offset $\sim 0.19 \log _{10}\left(\mathrm{~mol} \mathrm{C} \mathrm{m} \mathrm{C}^{-2} \mathrm{~d}^{-1}\right)$ and consequently had the highest RMSE (0.149 $\log _{10}\left(\mathrm{~mol} \mathrm{C} \mathrm{m} \mathrm{C}^{-2} \mathrm{~d}^{-1}\right)$; Table 2). However, the slope of the regression was the closest to $1(0.77$; Eq. 13 in Table 1). Although $\mathrm{PP}_{\mathrm{M} 91}$ also overestimated $\mathrm{PP}_{\text {eu }}$ it performed better at predicting high PP and consequently had an intermediate RMSE $\left(0.137 \log _{10}(\mathrm{~mol}\right.$ $\left.\left.\mathrm{C} \mathrm{m}^{-2} \mathrm{~d}^{-1}\right)\right) . \mathrm{PP}_{\mathrm{APH}}$ had the highest prediction capability with the smallest RMSE $\left(0.021 \log _{10}(\mathrm{~mol} \mathrm{C}\right.$ $\left.\mathrm{m}^{-2} \mathrm{~d}^{-1}\right)$ ) and the lowest scatter around the regression $\left(R^{2}=0.71\right)$ and a slope close to 1 (Fig. 9a; Eq. 11 in Table 1). $\mathrm{PP}_{\mathrm{APH}}$ also yielded the lowest RPD and $\mathrm{APD}$, indicating minimum biases and uncertainties, respectively. $F_{\text {med, }} F_{\min }$ and $F_{\max }$ indicate which algorithm(s) is more accurate at the low (min), medium (med) and maximum (max) values over the range tested; the more accurate the algorithm, the closer $F$ is to $1 . \mathrm{PP}_{\mathrm{APH}}$ was closer to 1 for $\mathrm{F}_{\text {med, }}, \mathrm{F}_{\text {min }}$ and $\mathrm{F}_{\max }$ (Table 2). $\mathrm{PP}_{\mathrm{VGPM}}$ and $\mathrm{PP}_{\mathrm{M} 91}$ had a tendency to over-estimate by a factor of $>3$ at medium range values and a factor of $\sim 6$ at the higher range values.

\section{Size-fractionated production}

Size-fractionated PP was measured during 6 periods from 2009 to 2011; twice in winter, 3 times in spring and twice in summer (Fig. 10). The highest production was recorded at the end of August 2009 and the beginning of April 2011 (Fig. 10A,D) when $\mathrm{PP}_{\text {eu }}$ reached 0.155 and $0.099 \mathrm{~mol} \mathrm{C} \mathrm{m}^{-2} \mathrm{~d}^{-1}$, respectively. During these periods, depth-integrated chl a

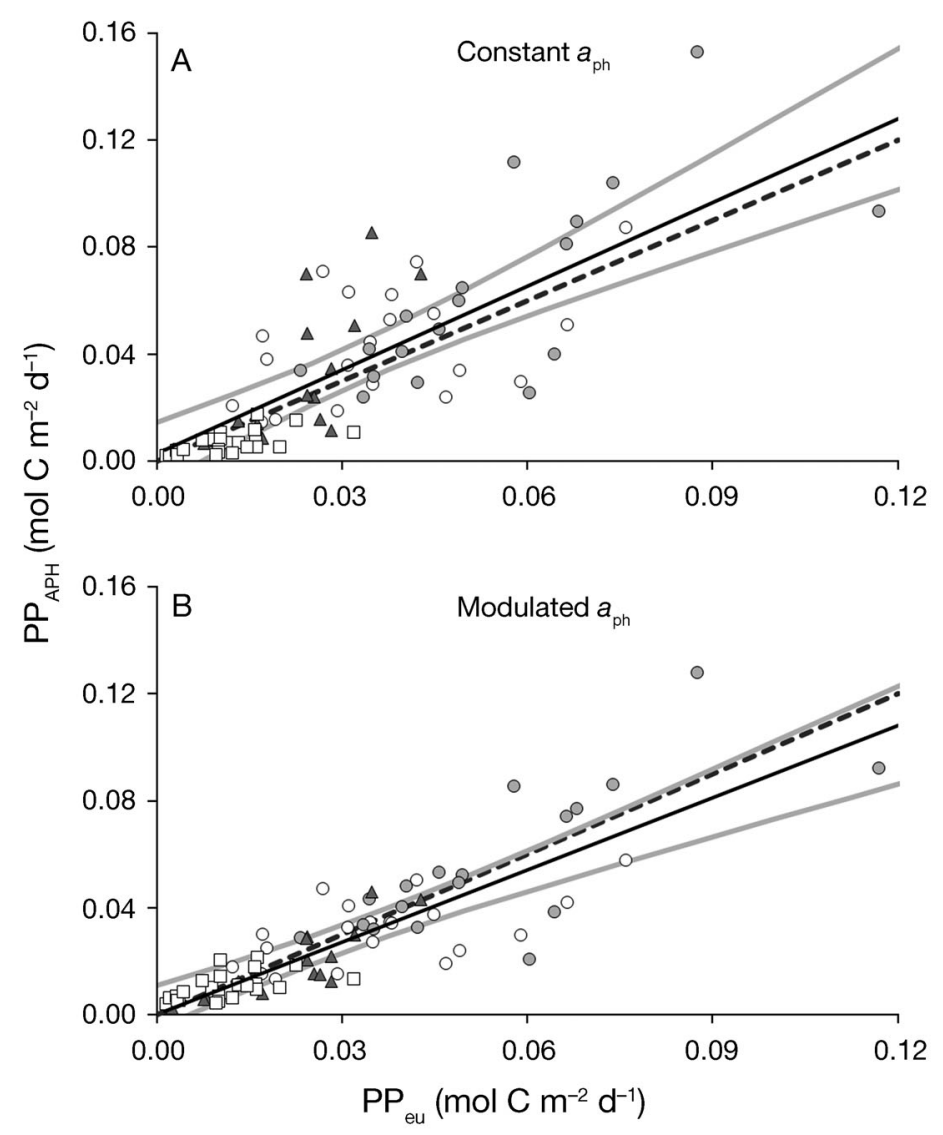

Fig. 8. Modelled depth-integrated production $\mathrm{PP}_{\mathrm{APH}}$ calculated using Eq. (4) in Table 1, assuming (A) constant $a_{\text {ph }}$ and (B) depthresolved $a_{\mathrm{ph}}$ plotted against in situ daily integrated $\mathrm{PP}\left(\mathrm{PP}_{\mathrm{eu}}\right)$. Linear regressions, 95\% confidence intervals and 1:1 relationships (dashed lines) are shown for each 

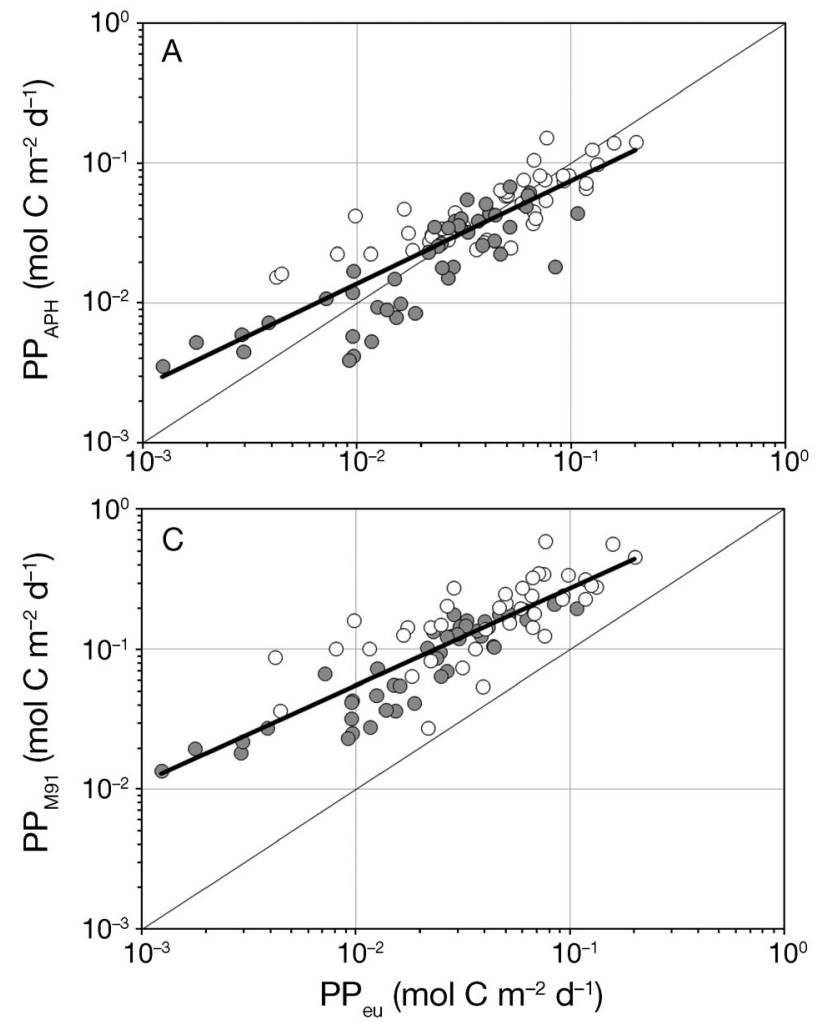

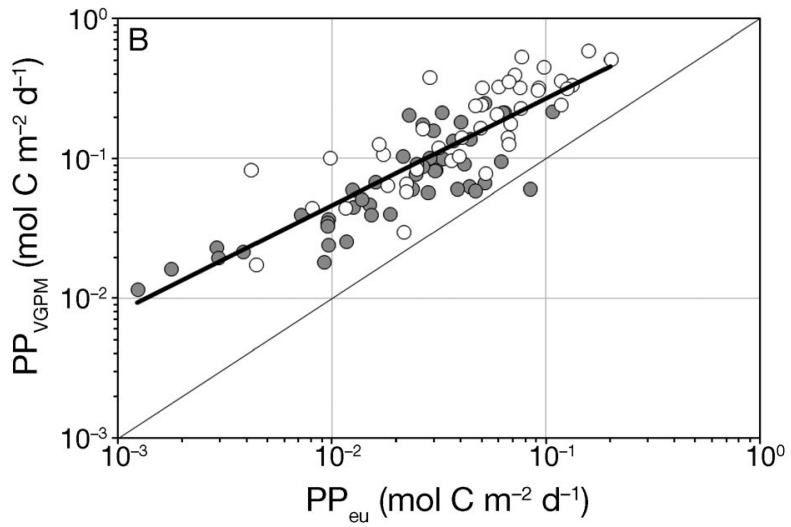

Fig. 9. Skill assessment of depth-integrated (A) $\mathrm{PP}_{\mathrm{APH}}(\mathrm{B})$ $\mathrm{PP}_{\mathrm{VGPM}}$ and (C) $\mathrm{PP}_{\mathrm{M} 91}$ plotted against $\mathrm{PP}_{\mathrm{eu}}$ for the Western English Channel from 2010 to 2011 (closed circles) and the North Sea and Oosterschelde from 1999 to 2012 (open circles). $\mathrm{PP}_{\mathrm{APH}}$ was calculated with Eq. (7b), using vertically modulated $a_{\mathrm{ph}}$, whereas $\mathrm{PP}_{\mathrm{VGPM}}$ and $\mathrm{PP}_{\mathrm{M} 91}$ were calculated from in situ chl a measurements

Table 2. Performance indices for relative errors in production models compared with in situ data. The algorithms with the highest precision are highlighted in bold. N: number of data used; RPD: relative percentage difference; APD: apparent percentage difference; R2: percentage variability explained; RMSE: root-mean square error; $F_{\operatorname{med}}, F_{\min }$ and $F_{\text {max }}$ : geometric mean and one-sigma range of the ratio Value alg:Value $_{\text {meas }}$ (where alg is algorithm and meas is measured); PP: primary production; APH: absorption coefficient of phytoplankton; WEC: Western English Channel; NS: North Sea and Oosterschelde; M91: wavelength resolving model; VGPM: vertical generalized production model; see 'Materials and methods: PP model comparisons' for further details of these models

\begin{tabular}{|c|c|c|c|c|c|c|c|c|}
\hline & $\mathrm{N}$ & $\mathrm{RPD}$ & $\mathrm{APD}$ & $\mathrm{R}^{2}$ & RMSE & $\mathrm{F}_{\text {med }}$ & $\mathrm{F}_{\max }$ & $\mathrm{F}_{\min }$ \\
\hline $\mathrm{PP}_{\mathrm{APH}(\mathrm{WEC})}$ & 46 & 8.3 & 43.6 & 0.703 & 0.016 & 0.94 & 1.62 & 0.55 \\
\hline $\mathrm{PP}_{\mathrm{M} 91(\mathrm{WEC})}$ & 46 & 304.2 & 304.7 & 0.726 & 0.073 & 3.52 & 5.98 & 2.07 \\
\hline $\mathrm{PP}_{\mathrm{VGPM}(\mathrm{WEC})}$ & 46 & 286.9 & 288.1 & 0.681 & 0.080 & 3.34 & 5.86 & 1.90 \\
\hline $\mathrm{PP}_{\mathrm{APH}}$ & 87 & 22.0 & 51.6 & 0.712 & 0.021 & 1.04 & 1.81 & 0.60 \\
\hline $\mathrm{PP}_{\mathrm{M} 91}$ & 87 & 360.3 & 360.6 & 0.668 & 0.137 & 3.82 & 6.90 & 2.11 \\
\hline $\mathrm{PP}_{\mathrm{VGPM}}$ & 87 & 324.7 & 325.4 & 0.711 & 0.149 & 3.62 & 6.32 & 2.07 \\
\hline
\end{tabular}

(TChla) was largely dominated by micro-phytoplankton with an average contribution of $65 \%$ reaching a maximum of $89 \%$ on 11 April 2011 and 24 August 2009 when micro-phytoplankton production was 0.021 and $0.013 \mathrm{~mol} \mathrm{C} \mathrm{m}^{-2} \mathrm{~d}^{-1}$, respectively (Fig. 10). Nano-phytoplankton was the major contributor to TChla on just 2 days, reaching $63 \%$ on 4 May 2010 and 11 August 2010 when nano-phytoplankton production was $0.017 \mathrm{~mol} \mathrm{C} \mathrm{m}^{-2} \mathrm{~d}^{-1}$ and micro-phytoplankton accounted for just $28 \%$ of TChla. Picophytoplankton contributed between 2 and $13 \%$ of
TChla at Stn L4 during the selected periods. Microphytoplankton was also a dominant contributor to $\mathrm{PP}_{\mathrm{eu}}$ over most of the observations but less than for TChla (Fig. 10C). Percentage contributions of micro-, nano- and pico-phytoplankton ranged between 20 and $80 \%, 13$ and $52 \%$ and 4 and $56 \%$ respectively, with micro-phytoplankton expectedly more dominant when phytoplankton biomass and production were highest (Fig. 10C,D). The average photosynthetic parameters $\alpha^{\mathrm{B}}, P_{\mathrm{m}}^{\mathrm{B}}$ and $\mathrm{E}_{\mathrm{k}}$ for each size fraction during each period are shown in Table 2. Both the 

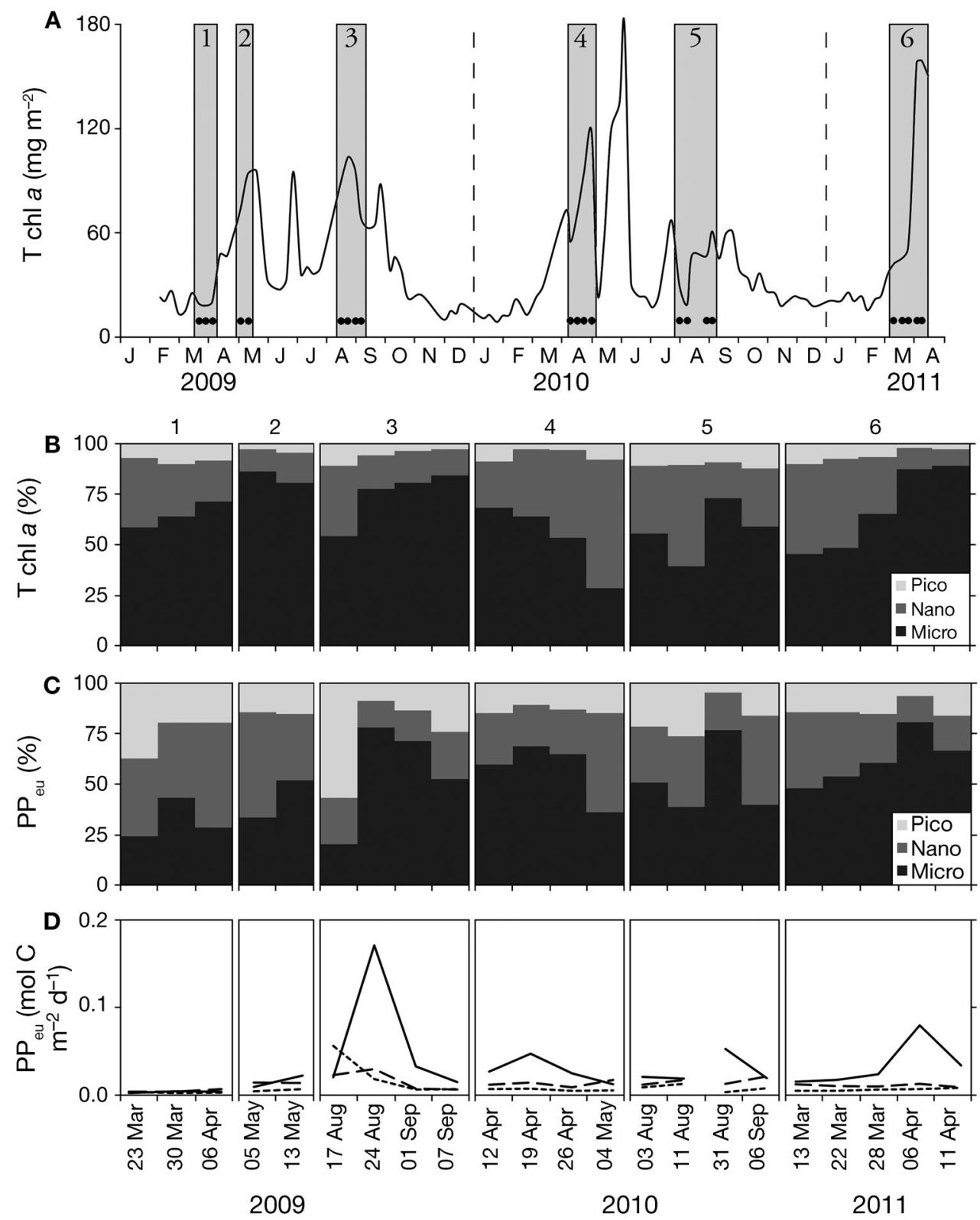

Fig. 10. Size-fractionated chl $a$ and primary production $\mathrm{PP}_{\mathrm{eu}}$ data collected from the Western English Channel during 2009 to 2011. (A) Sampling periods (bars; black dots are sampling events). Dashed lines separate years. (B) Percentage of total chl a (TChla) in 3 size fractions during the 6 sampling periods. (C) Percentage of $\mathrm{PP}_{\mathrm{eu}}$ in 3 size fractions. (D) Integrated PP $\mathrm{eu}_{\mathrm{mol}} \mathrm{C}$ $\mathrm{m}^{-2} \mathrm{~d}^{-1}$ ); solid line is total, long-dash line is micro-, and short-dash line is nano+pico-phytoplankton primary production

light-limited slope $\alpha^{\mathrm{B}}$ and the light-saturated rate of photosynthesis $P_{\mathrm{m}}{ }^{\mathrm{B}}$ are approximately double for picoplankton $\left(0.044 \mathrm{mg} \mathrm{C}(\mathrm{mg} \mathrm{chl} \mathrm{a})^{-1} \mathrm{~h}^{-1}\right.$ ( $\mu \mathrm{mol}$ photons $\left.\mathrm{m}^{-2} \mathrm{~s}^{-1}\right)^{-1}$ and $8.09 \mathrm{mg} \mathrm{C}(\mathrm{mg} \mathrm{chl} \mathrm{a})^{-1} \mathrm{~h}^{-1}$, respectively) than for nano- or microplankton which have, on average, similar values of $\alpha^{\mathrm{B}}$ and $P_{\mathrm{m}}{ }^{\mathrm{B}}$. The light saturation parameter $\mathrm{E}_{\mathrm{k}}$ was more consistent between size fractions with $E_{\mathrm{k}} 21 \%$ higher, on average, for microphytoplankton. However, $\alpha^{\mathrm{B}}$ and $P_{\mathrm{m}}{ }^{\mathrm{B}}$ exhibited large variations both between and within peri- ods with an overall CV of ca. 80 and $65 \%$, respectively. The $442: 665 \mathrm{~nm} a_{\mathrm{ph}}$ ratio varied by 1.37 times, with lower ratio values corresponding to higher micro-phytoplankton chl a biomass and higher ratio values corresponding to higher nano-phytoplankton chl a biomass (Table 3).

The relationship between chl $a$ and $a_{\mathrm{ph}}(665)$ for total chl $a$ and when micro- and nano+pico phytoplankton were $>50 \%$ is given in Fig. 11. Although there is a slight shift upwards for the micro-phyto- 


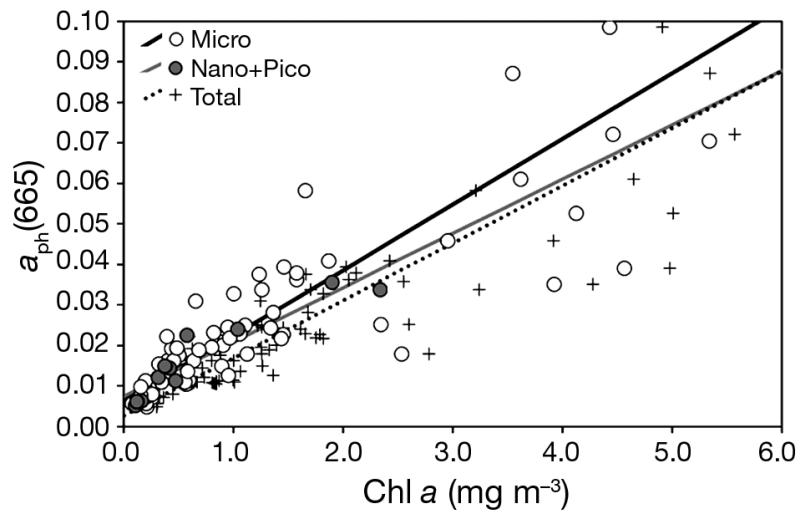

Fig. 11. Relationship between chl $a$ and $a_{\mathrm{ph}}(665)$ for total chl a (crosses) and micro-phytoplankton (open circles) and nano+pico-phytoplankton (closed circles) when each of the size fractions comprises $>50 \%$ of the total $\mathrm{chl} a$

plankton, there was no significant difference between total chl a, micro- and nano+pico phytoplankton (ANCOVA $F_{1,75}=0.19, \mathrm{p}=0.664$ ), indicating that absorption in these size fractions is linearly related to chl $a$. The relationship between depthspecific production $\mathrm{PP}_{\mathrm{z}}$ and phytoplankton light absorption $\left(E_{\mathrm{PAR}} \times a_{\mathrm{ph}}(665)\right)$ for both micro-phytoplankton $\left(\mathrm{PP}_{\mathrm{z}}(\mathrm{M})\right)$ and nano+pico-phytoplankton $\left(\mathrm{PP}_{\mathrm{z}}(\mathrm{N})\right)$ is given in Fig. 12. For both size fractions, a strong linear regression was observed explaining 82 and $87 \%$ of $\mathrm{PP}_{\mathrm{z}}(\mathrm{M})$ and $\mathrm{PP}_{\mathrm{z}}$, respectively (Eqs. 13 and 14 in Table 1). Regressions for both size groups were significantly different $(F=46.0, \mathrm{p}<0.001)$.

\section{DISCUSSION}

\section{Phytoplankton absorption: a predictor of coastal PP}

The coastal zone accounts for a large percentage of global ocean PP and of the new production, and therefore improvements in modelling PP in these optically complex waters are fundamental to enhance our understanding of the carbon cycle. Phytoplankton absorption provides a simple and practical alternative to estimating PP in coastal waters. The main hypothesis tested was that phytoplankton light absorption is a good first-order predictor of PP in coastal waters. Our results suggest that phytoplankton absorption is a strong predictor of depth-specific PP throughout the water column at a time series station in the WEC. Combined with irradiance, phytoplankton absorption explained $88 \%$ of the variation in surface production. Further independent data were obtained from other coastal and estuarine waters of the North Sea, and this algorithm also proved to be accurate when applied to these waters. Phytoplankton light absorption is linked to both phytoplankton biomass and physiology through varying concentrations of light-harvesting pigments. Phytoplankton absorption has therefore been used to detect harmful algal blooms, analyse their abundance (Millie et al. 1997) or characterise the succession and dynamics of phytoplankton (Lee et al. 2011). Marra et al. (2007) showed that, in open ocean waters, a linear rela-

Table 3. Mean $( \pm \mathrm{SD})$ photosynthetic parameters: chlorophyll normalised light limited slope $\left(\alpha^{\mathrm{B}}, \mathrm{mg} \mathrm{C}\left(\mathrm{mg} \mathrm{Chl}^{-1} \mathrm{~h}^{-1}\left(\mu \mathrm{mol} \mathrm{m} \mathrm{m}^{-2}\right.\right.\right.$ $\left.\left.\mathrm{s}^{-1}\right)^{-1}\right)$, assimilation number $\left(\mathrm{P}_{\mathrm{m}}{ }^{\mathrm{B}}, \mathrm{mg} \mathrm{C}(\mathrm{mg} \mathrm{Chl})^{-1} \mathrm{~h}^{-1}\right)$ and light saturation parameter $\left(\mathrm{E}_{\mathrm{k}}, \mu \mathrm{mol} \mathrm{m}^{-2} \mathrm{~s}^{-1}\right)$ for 3 different size fractions (micro: $>10 \mu \mathrm{m}$, nano: $2-10 \mu \mathrm{m}$, pico: $0.2-2 \mu \mathrm{m}$ ) and absorption coefficient of phytoplankton $\left(a_{\mathrm{ph}}\right) \mathrm{ratio}$ at $442: 665 \mathrm{~nm}$ (blue:red, B:R) during 6 size-fractionated sampling periods

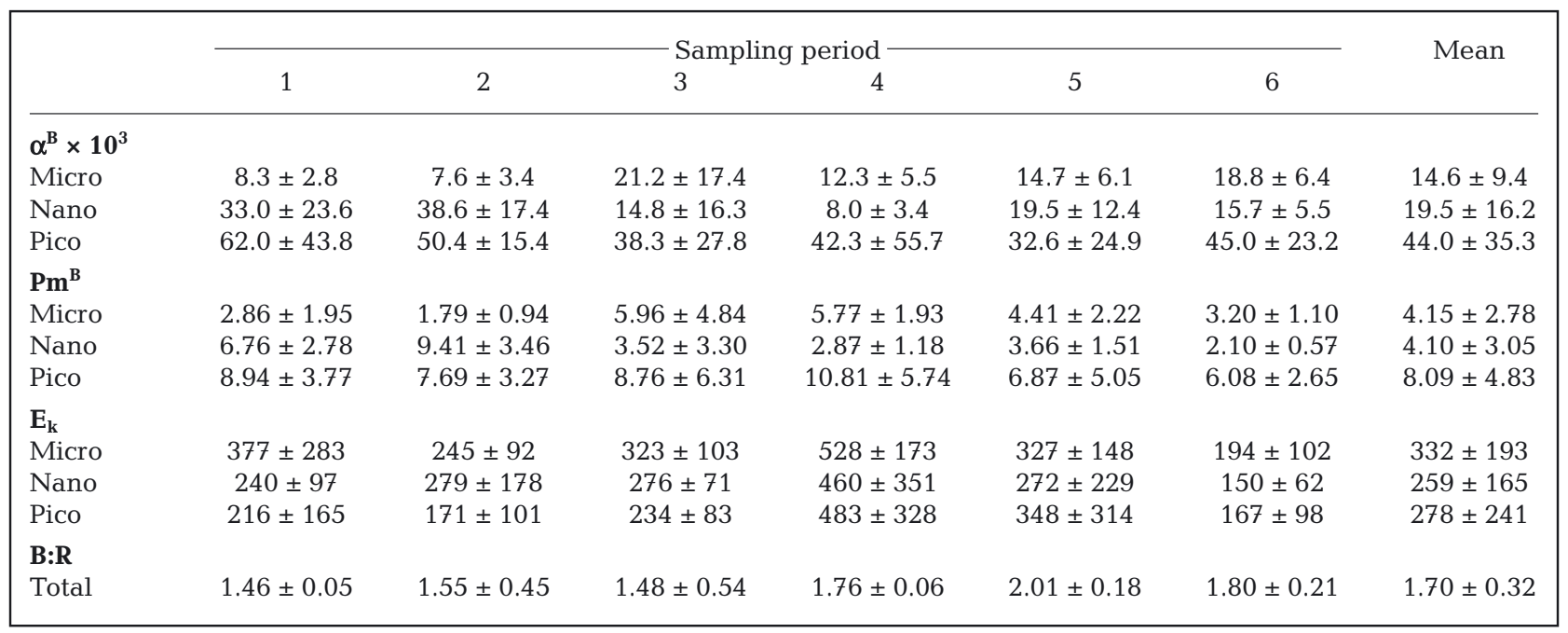


Fig. 12. (A) Relationship between $\mathrm{PP}_{\mathrm{z}}$ and the product of $E_{\mathrm{PAR}}$ by $\mathrm{a}_{\mathrm{ph}}(665)$ for micro-phytoplankton (open circles) and nano+pico-phytoplankton (closed circles) for data collected from 2009 to 2011. Log-linear regressions, their equations and $\mathrm{R}^{2}$ values are given in Table 1 . (B) Same relationships using just surface data

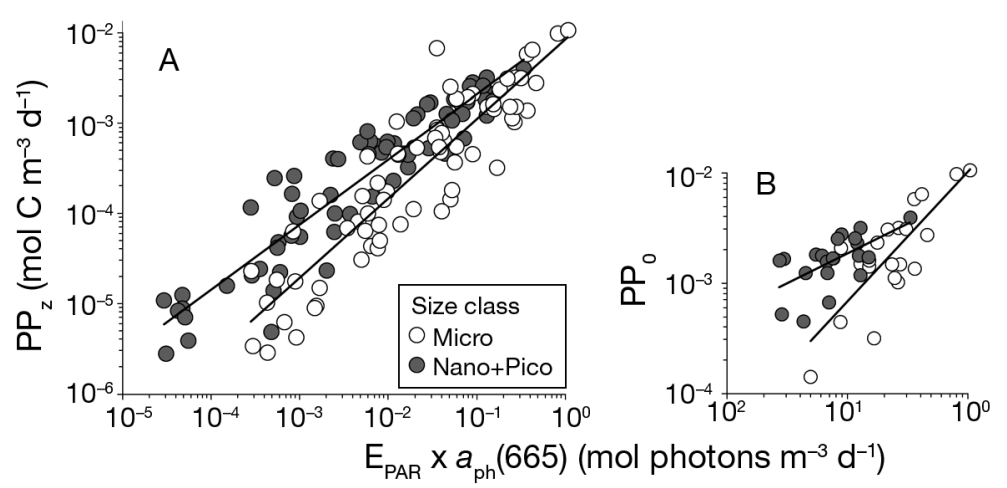

tionship existed between spectrally-averaged $a_{\mathrm{ph}}$ and $\mathrm{PP}_{0}$. We extended this approach to (1) different wavebands, (2) vertically through the water column, (3) different size fractions and (4) optically complex coastal waters. The absorption-based model performed better using $a_{\mathrm{ph}}(665)$ than $a_{\mathrm{ph}}(442)$ or $a_{\mathrm{ph}}(\mathrm{PAR}) . a_{\mathrm{ph}}(665)$ corresponds to the red peak of chl $a$ absorption, where the influence of both $a_{\mathrm{CDOM}}$, $a_{\text {NAP }}$ and accessory pigments are minimal (Fig. 2). The relationship between $a_{\mathrm{ph}} \times E_{\mathrm{PAR}}$ and $\mathrm{PP}_{\mathrm{z}}$ was conserved throughout the water column for both total and size-fractionated production, which justified the extension to a total column production model and suggests light saturation. The model performed best with vertically heterogeneous $a_{\mathrm{ph}}$ modelled from CTD fluorescence profiles rather than with the vertical homogeneity assumed by some production models (e.g. Behrenfeld \& Falkowski 1997). The VGPM is designed to retrieve values closer to net PP rather than gross PP. Since gross PP is greater than net PP, the over-estimate in VGPM at lower PP values (Fig. 9) would ultimately be worse when the VGPM values are converted to gross PP. In recent years, Hirawake et al. (2011) used phytoplankton absorption instead of chl $a$ in the VGPM and, by estimating water column primary production independently of sea surface temperature (SST), were able to show over- and under-estimation of the SST-dependent model in warmer and colder waters, respectively, in the Southern Ocean. Shang et al. (2010) observed that an absorption-based model performed better in the Southern Ocean than those based on either chl a or estimates of phytoplankton carbon, thereby replicating the methods and findings of Lee et al. (1996) in Icelandic waters. The more complex semi-analytical model M91 (Morel 1991, Antoine et al. 1996) included a spectral and depth dependency which could be improved with knowledge of CDOM and TSM concentrations (Smyth et al. 2005). However, chlorophyll-based models of productivity have been shown to overestimate productivity when CDOM is high in the water column (Tilstone et al. 2005) or underestimate productivity in diatom-dominated waters due to the package effect (Hirawake et al. 2000). This may also be the case in coccolithophorid-dominated waters where scattering is greater than absorption. In open ocean waters, phytoplankton is usually the predominant absorbing constituent and other constituents co-vary with chl a (Morel \& Prieur 1977). In coastal waters as well as inland and estuarine waters, however, TSM and CDOM dominate the optical signal and may not co-vary with chl $a$ concentration. The accuracy of this satellite-retrieval of chl $a$ is thus dependent on the optical characteristics of the water body and is greatly reduced in coastal waters (Tilstone et al. 2012). For these reasons, the use of IOPs over chl a has become increasingly accepted (Huot et al. 2007). Phytoplankton absorption used in this study is not normalised to chl $a_{i}$ therefore, it overcomes the problems of packaging effects, whereby cell volume and the arrangement of chlorophyll within the cell contribute to its effective absorption. $a_{\mathrm{ph}}$ has great potential as a direct and practical parameter from which photosynthetic rates can be estimated. We have shown that accurate parameterisation of an $a_{\mathrm{ph}}$ based productivity model at one coastal location can be accurately used to predict PP at other coastal sites.

Decades of field study have found that phytoplankton absorption spectra vary in their spectral shape with differences due to varying pigment composition (Jeffrey et al. 1997) or cell sizes (Ciotti et al. 2002). A major application of this has been the development of methods to observe the variability in phytoplankton size structure using in situ or remote sensing optical measurements of either absorption spectra (Ciotti et al. 2002, Hirata et al. 2008), phytoplankton pigments (Vidussi et al. 2001) or chl a (Uitz et al. 2006, Brewin et al. 2010b). Marine carbon cycling is specif- 
ically linked to the activity of particular functional types and size classes (Le Quéré et al. 2005). However, only recently have attempts been made to extend these approaches towards a model of phytoplankton size class-specific production (Kameda \& Ishizaka 2005, Hirata et al. 2009, Brewin et al. 2010a, Uitz et al. 2010). Most have combined size-fractionated chlorophyll estimates (e.g. Mouw \& Yoder 2010) with chlorophyll-based production models, e.g. VGPM (Kameda \& Ishizaka 2005) or the Morel 91 model (Uitz et al. 2010), which are better adapted to open-ocean waters. Hirata et al. (2009) used satellite observations to investigate the possibility of estimating surface production by fitting a linear regression between production and estimates of $a_{\mathrm{ph}}(443)$. This analysis, however, was limited by the small number of measurements of in situ production or $a_{\mathrm{ph}}$ and the lack of measurements of in situ size-fractionated production.

In our study, by combining in situ measurements of $\mathrm{PP}_{0}$ and $a_{\mathrm{ph}}$ with the approach of Vidussi et al. (2001) and the coefficient weightings for the pigment ratios of micro- and nano+pico given by Uitz et al. (2006) to estimate $a_{\mathrm{ph}}$ in the different size fractions, a convincing model of both $\mathrm{PP}_{0}(\mathrm{M})$ and $\mathrm{PP}_{0}(\mathrm{NP})$ was constructed for application to coastal waters. In a recent study by Brewin et al. (2014), good agreement was demonstrated between size-fractionated chl a from fluorometric analyses of phytoplankton retained on different pore-sized polycarbonate filters and from values derived from HPLC using the coefficients given by Uitz et al. (2006), suggesting that the methodology to derive size-fractionated chl $a$ is robust. When the approach is used to split absorption into pico-, nano, and micro-phytoplankton, it is assumed that $a_{\mathrm{ph}}$ is linearly related to chl $a$, or that chlorophyll-specific absorption of phytoplankton in the 3 size fractions is the same, which in reality may not be the case (Ciotti et al. 2002, Hirata et al. 2008). At blue wavelengths such as $442 \mathrm{~nm}$, a combination of absorption by chl $a$ and accessory pigments causes differences in chlorophyll-specific absorption of pico-, nano-, and micro-plankton as a consequence of the packaging effects (Ciotti et al. 2002). In our dataset, we found that $\mathrm{a}_{\mathrm{ph}}(665)$ was linearly correlated with chl a (Fig. 11), suggesting that $a_{p h}(665)$ in micro- and nano+picophytoplankton can be accurately determined using this approach. We found that there was no significant difference in the linear regressions of $\mathrm{a}_{\mathrm{ph}}(665)$ and chl a for total, and micro- and nano+ pico-phytoplankton (ANCOVA $F_{1,75}=0.19, \mathrm{p}=0.664$; Table 1) when these fractions were $>50 \%$ of the total biomass (Fig. 10). Similarly, using PSICAM integrat- ing cavity in flow-through mode in the North Sea, Wollschläger et al. (2013) also showed that $\mathrm{a}_{\mathrm{ph}}(665)$ is linearly related to chl $a$. Further verification of these trends in different size classes of phytoplankton would ultimately benefit from the development of direct and independent methods for the determination of size-fractionated phytoplankton absorption coefficients.

In the WEC, we found higher $\mathrm{P}_{\mathrm{m}}{ }^{\mathrm{B}}$ and $\alpha^{\mathrm{B}}$ for nano+pico- than micro- phytoplankton, whereas $E_{k}$ was higher for micro- compared to nano+picophytoplankton (Table 3), consistent with Kameda \& Ishizaka (2005). By comparison, both the slope and the offset of the regression between PP and $a_{\mathrm{ph}}(665)$ $\times E_{\mathrm{PAR}}$ were lower for nano+pico-phytoplankton, suggesting that in contrast to the micro-phytoplankton, these smaller fractions (1) exhibit a relatively higher quantum yield of carbon fixation, (2) are more high-light acclimated and/or (3) are not nutrient limited.

Our approach provides a simple means of estimating coastal PP for different size classes. The application of this size-fractionated method requires further validation in other coastal waters which have greater variability in dominance of each size class. Further independent analyses in different geographical locations are required to evaluate the global applicability of this absorption-based approach of estimating coastal productivity.

Some red-near infra red (NIR) band ratio algorithms have already been applied to satellite data; for example Dall'Olmo \& Gitelson (2005) used SeaWiFS and MODIS data to estimate chl $a$ in turbid productive waters by using NIR-to-red reflectance ratios to estimate $a_{p h}(\lambda)$ and $b_{p}(\lambda)$. The main obstacle in achieving accurate retrievals for these products has been the lack of an operational atmospheric correction scheme over turbid waters specific for the red and NIR bands. Similarly Gitelson et al. (1999) analysed the reflectance spectra of the bacterio-chl $a$ containing cyanobacterium Thiocapsa roseopersicina to assess the potential of detecting it using remote sensing data in reservoirs. Reflectance spectra of $T$. roseopersicina in culture showed a trough in the green between 550 and $570 \mathrm{~nm}$, a peak at $625 \mathrm{~nm}$ due to phycocyanin and a peak between 670 and $680 \mathrm{~nm}$ corresponding to chl a absorption maximum and a minimum in the red-NIR at $700 \mathrm{~nm}$. It was found that the area delimited by the baseline from 760 to $930 \mathrm{~nm}$ could be used as an indicator of the photosynthetic bacterial population. The errors associated with the retrieval of $\mathrm{nL}_{\mathrm{w}}(665)$ by ocean colour satellites (e.g. Antoine et al. 2008), however, does not 
currently preclude the application of this model to remotely sensed data. A range of novel atmospheric correction procedures for turbid waters have been developed and applied to multi-spectral sensors (e.g. Ruddick et al. 2000). These show promising improvements in the retrieval of $\mathrm{nL}_{\mathrm{w}}$ in both the blue and red spectrum, although these are still not always applied on an operational basis. The development of new satellite algorithms such MERIS COASTCOLOUR which have improved the accuracy of $\mathrm{nL}_{\mathrm{w}}$ could mean that such an algorithm could be applied to satellite data in the future.

Recent developments in optical sensors have enabled flow-through and/or continuous measurements of particulate, dissolved and phytoplankton absorption that are comparable with discrete filter pad measurements (Slade et al. 2010). Derivation of biogeochemical variables from these instruments has been demonstrated (Stramski et al. 2008). In addition, red- and/or NIR-based optical algorithms have been successfully applied to aircraft data. For example, a bio-optical model using Hyperion data was parameterised using specific IOPs measured in Lake Garda, the largest Italian Lake (Giardino et al. 2007). A MODTRAN-based atmospheric correction code, complemented with an air-water interface correction was used to convert Hyperion radiances into subsurface irradiance reflectance to accurately estimate absorption and backscattering coefficients at red bands, which were then used to derive ocean colour products. The PP algorithm derived in this paper for the WEC, and validated in the North Sea, could be applied to optical sensors on autonomous platforms (such as buoys, ferryboxes, gliders or remotely operated vehicles), aircraft and satellite data that are accurate at red wavebands.

\section{CONCLUSIONS}

A simple method for estimating coastal PP as total, micro and nano+pico from phytoplankton absorption and irradiance was developed, which performed better than chlorophyll-based approaches. The method was tested on (1) specific wavebands, (2) adapted to generate vertical profiles of production in the water column and therefore integrated production, (3) to derive micro- and nano+pico-phytoplankton production, and (4) was tested in other optically complex coastal waters. The method is accurate to $8 \%$ in the WEC and $22 \%$ in estuarine and coastal waters of the North Sea and WEC.
Acknowledgements. M.K.B. was supported by a NERC studentship (NE/F012608/1). G.H.T. and T.J.S.M. were supported by the NERC National Capability Western English Channel Observatory. G.H.T. was also supported by the European Union contract Information System on the Eutrophication of our Coastal Seas (ISECA) (Contract no. 07027-FR-ISECA) funded by INTERREG IVA 2 Mers Seas Zeeen Cross-border Cooperation Programme 2007-2013. Processing of PP models was facilitated by the Natural Environment Research Council (NERC) Earth Observation Data Acquisition and Analysis Service (NEODAAS) linux cluster at Plymouth Marine Laboratory.

\section{LITERATURE CITED}

Antoine D, Andre JM, Morel A (1996) Oceanic primary production 2. Estimation at global scale from satellite (coastal zone color scanner) chlorophyll. Global Biogeochem Cycles 10:57-69

Antoine D, d'Ortenzio F, Hooker SB, Becu G, Gentili B, Tailliez D, Scott AJ (2008) Assessment of uncertainty in the ocean reflectance determined by three satellite ocean color sensors (MERIS, SeaWiFS and MODIS-A) at an offshore site in the Mediterranean Sea (BOUSSOLE project). J Geophys Res 113:C07013, doi: 10.1029/2007 JC004472

$>$ Barlow RG, Cummings DG, Gibb SW (1997) Improved resolution of mono- and divinyl chlorophylls $a$ and $b$ and zeaxanthin and lutein in phytoplankton extracts using reverse phase C-8 HPLC. Mar Ecol Prog Ser 161:303-307

Behrenfeld MJ, Falkowski PG (1997) Photosynthetic rates derived from satellite-based chlorophyll concentration. Limnol Oceanogr 42:1-20

Brewin RJW, Lavender SJ, Hardman-Mountford NJ (2010a) Mapping size-specific phytoplankton primary production on a global scale. J Maps 2010:448-462

$>$ Brewin RJW, Lavender SJ, Hardman-Mountford NJ, Hirata $\mathrm{T}$ (2010b) A spectral response approach for detecting dominant phytoplankton size class from satellite remote sensing. Acta Oceanol Sin 29:14-32

> Brewin RJW, Sathyendranath S, Lange PK, Tilstone GH (2014) Comparison of two methods to derive the sizestructure of natural populations of phytoplankton. DeepSea Res I 85:72-79

> Campbell J, Antoine D, Armstrong R, Arrigo K and others (2002) Comparison of algorithms for estimating ocean primary production from surface chlorophyll, temperature, and irradiance. Global Biogeochem Cycles 16: art1035, doi:10.1029/2001GB001444

Ciotti AM, Lewis MR, Cullen JJ (2002) Assessment of the relationships between dominant cell size in natural phytoplankton communities and the spectral shape of the absorption coefficient. Limnol Oceanogr 47:404-417

Cullen JJ, Lewis MR (1995) Biological processes and optical measurements near the sea-surface: some issues relevant to remote sensing. J Geophys Res 100:13255-13266

Cullen JJ, Lewis MR, Davis CO, Barber RT (1992) Photosynthetic characteristics and estimated growth-rates indicate grazing is the proximate control of primary production in the equatorial Pacific. J Geophys Res 97:639-654

Dall'Olmo G, Gitelson AA (2005) Effect of bio-optical parameter variability on the remote estimation of chlorophyll-a concentration in turbid productive waters: experimental results. Appl Opt 44:412-422 
Falkowski PG, Kolber Z (1995) Variations in chlorophyll fluorescence yields in phytoplankton in the world oceans. Aust J Plant Physiol 22:341-355

Giardino C, Brando VE, Dekker AG, Strombeck N, Candiani G (2007) Assessment of water quality in Lake Garda (Italy) using Hyperion. Remote Sens Environ 109:183-195

Gitelson A, Stark R, Dor I, Michelson O, Yacobi YZ (1999) Optical characteristics of the phototroph Thiocapsa roseoparsicina and implications for real-time monitoring of the bacteriochlorophyll concentration. Appl Environ Microbiol 65:3392-3397

Gregg WW, Carder KL (1990) A simple spectral solar irradiance model for cloudless maritime atmospheres. Limnol Oceanogr 35:1657-1675

> Hirata T, Aiken J, Hardman-Mountford N, Smyth TJ, Barlow RG (2008) An absorption model to determine phytoplankton size classes from satellite ocean colour. Remote Sens Environ 112:3153-3159

Hirata T, Hardman-Mountford NJ, Barlow R, Lamont T, Brewin R, Smyth T, Aiken J (2009) An inherent optical property approach to the estimation of size-specific photosynthetic rates in eastern boundary upwelling zones from satellite ocean colour: an initial assessment. Prog Oceanogr 83:393-397

> Hirawake T, Takao S, Horimoto N, Ishimaru T, Yamaguchi Y, Fukuchi M (2000) Bio-optical relationships of case 1 waters: the difference between mid- and low-latitude waters of the Southern Ocean. J Oceanogr 56:245-260

- Hirawake T, Takao S, Horimoto N, Ishimaru T, Yamaguchi Y, Fukuchi M (2011) A phytoplankton absorption-based primary productivity model for remote sensing in the Southern Ocean. Polar Biol 34:291-302

> Huot Y, Babin M, Bruyant F, Grob C, Twardowski MS, Claustre H (2007) Relationship between photosynthetic parameters and different proxies of phytoplankton biomass in the subtropical ocean. Biogeosciences 4:853-868

Jeffrey SW, Mantoura RFC, Wright SW (1997) Phytoplankton pigments in oceanography. UNESCO, Paris

Kameda T, Ishizaka J (2005) Size-fractionated primary production estimated by a two-phytoplankton community model applicable to ocean color remote sensing. J Oceanogr 61:663-672

Kromkamp JC, Dijkman NA, Peene J, Simis SGH, Gons HJ (2008) Estimating phytoplankton primary production in Lake IJsselmeer (The Netherlands) using variable fluorescence (PAM-FRRF) and C-uptake techniques. Eur J Phycol 43:327-344

Le Quéré C, Harrison SP, Prentice IC, Buitenhuis ET and others (2005) Ecosystem dynamics based on plankton functional types for global ocean biogeochemistry models. Glob Change Biol 11:2016-2040

- Lee ZP, Carder KL, Marra J, Steward RG, Perry MJ (1996) Estimating primary production at depth from remote sensing. Appl Opt 35:463-474

> Lee Z, Lance VP, Shang S, Vaillancourt R and others (2011) An assessment of optical properties and primary production derived from remote sensing in the Southern Ocean (SO GasEx). J Geophys Res 116:C00F03, doi:10.1029/ 2010JC006747

> Lorenzen CJ (1967) Determination of chlorophyll and pheo-pigments: spectrophotometric equations. Limnol Oceanogr 12:343-347

> MacIntyre HL, Kana TM, Anning T, Geider RJ (2002) Photoacclimation of photosynthesis irradiance response curves and photosynthetic pigments in microalgae and cyanobacteria. J Phycol 38:17-38

> Marra J, Trees CC, O'Reilly JE (2007) Phytoplankton pigment absorption: a strong predictor of primary productivity in the surface ocean. Deep-Sea Res I 54:155-163

> Mathot S, Dandois JM, Lancelot C (1992) Gross and net primary production in the Scotia-Weddell Sea sector of the Southern Ocean during spring 1988. Polar Biol 12: 321-332

Millie DF, Schofield OM, Kirkpatrick GJ, Johnsen G, Tester PA, Vinyard BT (1997) Detection of harmful algal blooms using photopigments and absorption signatures: a case study of the Florida red tide dinoflagellate, Gymnodinium breve. Limnol Oceanogr 42:1240-1251

- Morel A (1991) Light and marine photosynthesis - a spectral model with geochemical and climatological implications. Prog Oceanogr 26:263-306

> Morel A, Maritorena S (2001) Bio-optical properties of oceanic waters: a reappraisal. J Geophys Res 106:7163-7180

Morel A, Prieur L (1977) Analysis of variations in ocean color. Limnol Oceanogr 22:709-722

Mouw CB, Yoder YA (2010) Optical determination of phytoplankton size composition from global SeaWiFS imagery. J Geophys Res 115:C12018, doi:10.1029/2010JC006337

> Murray AP, Gibbs CW, Longmore AR, Flett DJ (1986) Determination of chlorophyll in marine waters: intercomparison of a rapid HPLC method with full HPLC, spectrophotometric and fluorimetric methods. Mar Chem 19: 211-227

Platt T, Gallegos CL, Harrison WG (1980) Photoinhibition of photosynthesis in natural assemblages of marine phytoplankton. J Mar Res 38:687-701

> Pope RM, Fry ES (1997) Absorption spectrum (380-700 nm) of pure water. II. Integrating cavity measurements. Appl Opt 36:8710-8723

> Reed R (1977) On estimating insolation over the ocean. J Phys Oceanogr 7:482-485

Röttgers R, Gehnke S (2012) Measurement of light absorption by aquatic particles: improvement of the quantitative filter technique by use of an integrating sphere approach. Appl Opt 51:1336-1351

> Ruddick KG, Ovidio F, Rijkeboer M (2000) Atmospheric correction of SeaWiFS imagery for turbid coastal and inland waters. Appl Opt 39:897-912

Saba VS, Friedrichs MAM, Carr ME, Antoine D and others (2010) Challenges of modeling depth-integrated marine primary productivity over multiple decades: a case study at BATS and HOT. Global Biogeochem Cycles 24:GB3020, doi:10.1029/2009GB003655

Shang SL, Behrenfeld MJ, Lee ZP, O'Malley RT, Wei GM, Li YH, Westberry T (2010) Comparison of primary production models in the Southern Ocean-preliminary results. In: Hou W, Arnone R (eds) Proc SPIE 7678, Ocean sensing and monitoring II. 767808 (April 20, 2010)

Siegel DA, Westberry TK, O'Brien MC, Nelson NB and others (2001) Bio-optical modeling of primary production on regional scales: the Bermuda BioOptics project. DeepSea Res II 48:1865-1896

> Slade WH, Boss E, Dall'Olmo G, Langner MR and others (2010) Underway and moored methods for improving accuracy in measurement of spectral particulate absorption and attenuation. J Atmos Ocean Technol 27: 1733-1746

Smyth TJ, Tilstone GH, Groom SB (2005) Integration of radiative transfer into satellite models of ocean primary production. J Geophys Res Oceans 110:C10014, doi: 
10.1029/2004JC00278410.1029/2004JC002784

Smyth TJ, Fishwick JR, Al-Moosawi L, Cummings DG and others (2010) A broad spatio-temporal view of the Western English Channel observatory. J Plankton Res 32: 585-601

Stramski D, Reynolds RA, Babin M, Kaczmarek S and others (2008) Relationships between the surface concentration of particulate organic carbon and optical properties in the eastern South Pacific and eastern Atlantic Oceans. Biogeosciences 5:171-201

Suggett DJ, Moore CM, Hickman AE, Geider RJ (2009) Interpretation of fast repetition rate (FRR) fluorescence: signatures of phytoplankton community structure versus physiological state. Mar Ecol Prog Ser 376:1-19

Tassan S, Ferrari GM (1995) Proposal for the measurement of backward and total scattering by mineral particles suspended in water. Appl Opt 34:8345-8353

Tassan S, Ferrari GM (1998) Measurement of light absorption by aquatic particles retained on filters: determination of the optical pathlength amplification by the 'transmittance-reflectance' method. J Plankton Res 20: 1699-1709

Tilstone GH, Moore GF, Sorensen K, Doerffer R, Rottgers R, Ruddick KG, Pasterkamp R (2003a) Protocols for the validation of MERIS products in Case 2 waters. Proceedings from ENVISAT MAVT Conf, 20-24 October 2003, Frascatti, Italy. European Space Agency

Tilstone GH, Figueiras FG, Lorenzo LM, Arbones B (2003b) Phytoplankton composition, photosynthesis and primary production during different hydrographic conditions at the Northwest Iberian upwelling system. Mar Ecol Prog Ser 252:89-104

Tilstone GH, Smyth TJ, Gowen RJ, Martinez-Vicente V, Groom SB (2005) Inherent optical properties of the Irish Sea and their effect on satellite primary production algo-

Editorial responsibility: Antonio Bode, A Coruña, Spain rithms. J Plankton Res 27:1127-1148

Tilstone GH, Angel-Benavides IM, Pradhan Y, Shutler JD, Groom S, Sathyendranath S (2011) An assessment of chlorophyll-a algorithms available for SeaWiFS in coastal and open areas of the Bay of Bengal and Arabian Sea. Remote Sens Environ 115:2277-2291

> Tilstone GH, Peters SWM, van der Woerd HJ, Eleveld MA and others (2012) Variability in specific-absorption properties and their use in a semi-analytical ocean colour algorithm for MERIS in North Sea and Western English Channel coastal waters. Remote Sens Environ 118: 320-338

> Uitz J, Claustre H, Morel A, Hooker SB (2006) Vertical distribution of phytoplankton communities in open ocean: an assessment based on surface chlorophyll. J Geophys Res Oceans 111:C08005, doi:10.1029/2005JC003207

> Uitz J, Claustre H, Gentili B, Stramski D (2010) Phytoplankton class-specific primary production in the world's oceans: seasonal and interannual variability from satellite observations. Global Biogeochem Cycles 24:GB3016, doi:10.1029/2009GB003680

- Vidussi F, Claustre H, Manca BB, Luchetta A, Marty JC (2001) Phytoplankton pigment distribution in relation to upper thermocline circulation in the eastern Mediterranean Sea during winter. J Geophys Res Oceans 106: 19939-19956

Weibull W (1951) A statistical distribution function of wide applicability. J Appl Mech 18:293-297

Welschmeyer NA (1994) Fluorometric analysis of chlorophyll $a$ in the presence of chlorophyll $b$ and pheopigments. Limnol Oceanogr 39:1985-1992

> Wollschläger J, Grunwald M, Röttgers R, Peterson W (2013) Flow-through PSICAM: a new approach for determining water constituents absorption continuously. Ocean Dyn 63:761-775

Submitted: April 22, 2013; Accepted: January 30, 2014 Proofs received from author(s): April 11, 2014 